DIW BERLIN

Discussion

Papers

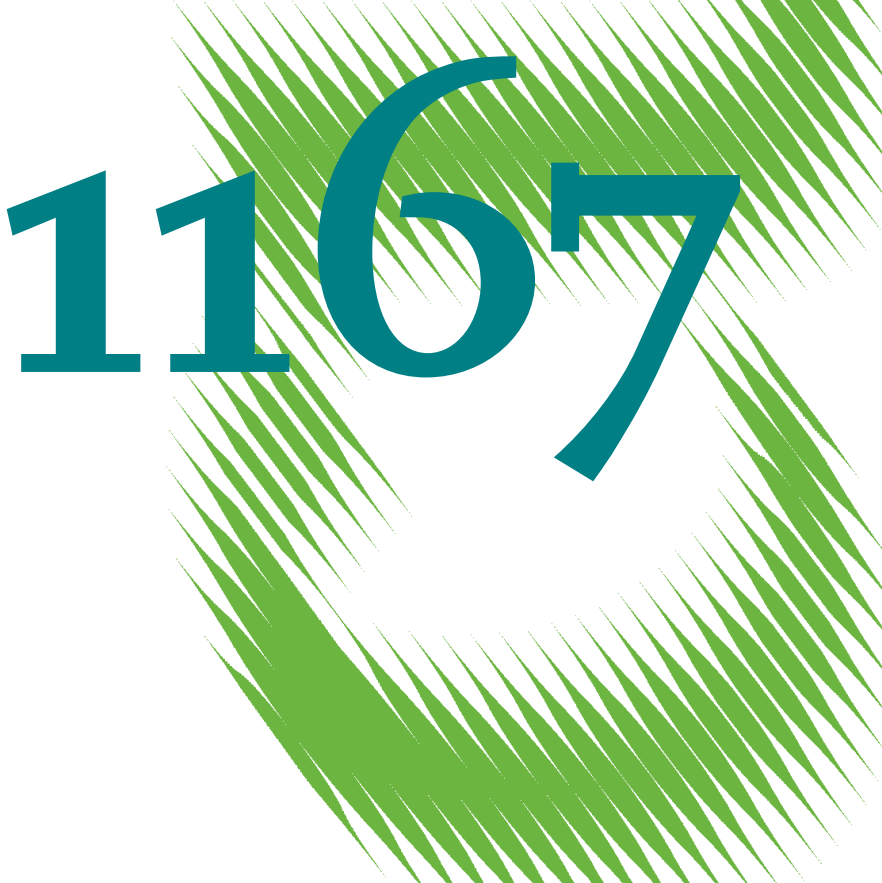

The Effect of Health and

Employment Risks on

Precautionary Savings 
Opinions expressed in this paper are those of the author(s) and do not necessarily reflect views of the institute.

IMPRESSUM

(C) DIW Berlin, 2011

DIW Berlin

German Institute for Economic Research

Mohrenstr. 58

10117 Berlin

Tel. $+49(30) 89789-0$

Fax +49 (30) $89789-200$

http://www.diw.de

ISSN print edition $1433-0210$

ISSN electronic edition 1619-4535

Papers can be downloaded free of charge from the DIW Berlin website:

http://www.diw.de/discussionpapers

Discussion Papers of DIW Berlin are indexed in RePEc and SSRN:

http://ideas.repec.org/s/diw/diwwpp.html

http://www.ssrn.com/link/DIW-Berlin-German-Inst-Econ-Res.html 


\title{
The effect of health and employment risks on precautionary savings
}

\author{
Johannes Geyer*
}

October 31, 2011

\begin{abstract}
This paper extends the idea of using ex-ante risk measures in a model of precautionary savings by explicitly simulating future net-income risks. The uncertainty measure takes into account the interdependency of labour market and health status. The model is estimated for prime age males using the German Socio-Economic Panel Study for years 2001-2007. The empirical analysis is conducted using a measure for savings stocks and savings flows. The latter model allows to control for individual specific effects. I find evidence for precautionary savings in response to the uncertainty measures. The results are robust and stable across specifications. There is evidence for a share of precautionary wealth of about 14 to 17 percent.
\end{abstract}

\section{Keywords: Precautionary Savings, Health, Employment, Risks}

JEL: D91, E21

Acknowledgments: The author wishes to thanks Viktor Steiner, Carsten Schröder, Michał Myck, Martin Browning, Peter Haan, Ronny Freier and participants at the International Conference on Pensions and Savings in Berlin for their helpful comments and assistance. Financial support from the German Science Foundation (DFG) through project "Economic risks, savings of the elderly, and the impact of public policy - an empirical analysis for Germany" (STE 681/8-1) is gratefully acknowledged. The usual disclaimer applies.

* DIW-Berlin, jgeyer@diw.de 


\section{Introduction}

The idea that individuals build up precautionary wealth because future income is random and not determinate was formally analysed by Leland (1968) for the first time and extended by the works of Sandmo (1970) and Dreze and Modigliani (1972). The theory predicts that individuals accumulate precautionary wealth to insure themselves against potential future income shocks. It gained importance in the context of the life-cycle hypothesis of consumption (Modigliani and Brumberg, 1954). The precautionary motive for accumulating wealth may be able to explain several so-called "consumption puzzles" that cannot be explained by traditional certainty or certainty-equivalence models (Zeldes, 1989). For example, it offers an explanation for the excess sensitivity of consumption to anticipated income fluctuations, the growth of consumption in the presence of a low real interest rate, and low spending of the elderly (Zeldes, 1989). Hubbard et al. (1995) argue that low wealth accumulation of many US households is not consistent with the traditional life-cycle model. They show that introducing uncertainty or precautionary savings can solve this puzzle. A large number of studies has been devoted to analyse the impact of income uncertainty ${ }^{1}$ on savings (a survey of the life-cycle model can be found in Browning and Crossley, 2001). The magnitude of individuals' reaction to income uncertainty by accumulating precautionary savings is expected to be higher the more risk averse individuals are. If this holds true for the economy in general, the quantitative relevance of the precautionary motive has important implications for government policies that affect income uncertainty (Aiyagari, 1994; Femminis, 2001; Kimball and Mankiw, 1989).

Although the theoretical concept appears to closely reflect everyday ideas of savings

1 The literature on precautionary savings does no distinguish between (measurable) risk and (immeasurable) uncertainty in a Knightian sense (Knight, 1921). In line with the literature, I use both concepts interchangeably and assume that both economic uncertainty and economic risk can be measured and operationalised with a probability distribution that is known to the individual. 
behaviour, empirical estimates of precautionary wealth are exceptionally diverse. The findings range from high shares of precautionary wealth in total wealth (e.g., Carroll and Samwick, 1997; Dardanoni, 1991; Engen and Gruber, 2001; Lusardi, 1998) to little or no precautionary wealth at all (e.g., Dynan, 1993; Guiso et al., 1992; Skinner, 1988). However, applied studies on the existence and significance of precautionary savings are confronted with a lot of conceptual and methodological problems, which might have contributed to the plurality of results (Browning and Lusardi, 1996; Kennickell and Lusardi, 2004).

The fundamental assumption underlying this model is that individuals assess the need for precautionary savings conditional on their expectations of future income risks. As a consequence, empirical studies applying this model have to find a reliable measure of income risk expectations that actually corresponds to households' risk expectations at the time savings decisions are made. Although the concept of precautionary savings relates current wealth to future income levels and shocks, and is thus related to individual expectations, the standard approach to model income risks in the literature is based on ex-post measures of household specific income variation. A likely reason for this restriction is the lack of good data on ex-ante risk expectations. Ex-post measures are likely to capture part of the expected income path, although only income fluctuations that have actually occurred and may also reflect choices. The focus on observed income fluctuations is restrictive because the scenarios that trigger precautionary saving will not inevitably occur. For example, it is plausible to assume that an employed individual saves money as a precaution against the risk of becoming unemployed. Usually, however, these kinds of savings decisions remain unobserved in survey data. Surveys that ask for saving motives usually find that the precautionary motive is important for savings (Alessie et al., 1997; Börsch-Supan and Essig, 2003; Kennickell and Lusardi, 2004; Schunk, 2009). The ideal ex-ante risk measure would have to comprise this counterfactual information as well. 
Only a few studies have considered ex-ante measures of economic risk. The most obvious indicators, which meet this criterion, probably are subjective assessments of economic risks. Unfortunately, these indicators often lack enough variation to identify an effect of income uncertainty on savings. However, some studies take advantage of detailed income risk assessments and simulate the corresponding ex-ante income variances (e.g., Arrondel, 2002; Guiso et al., 1992; Lusardi, 1997, 1998). Still, such detailed subjective data are rarely collected and not available for Germany. Moreover, the more realistic the respective set of questions is, the more complex and difficult to understand the questions get. A more flexible alternative is to simulate ex-ante risk scenarios and the corresponding income variance based on empirical estimates. This has been done using predicted unemployment risk - which is certainly one of the most important economic risks before retirement - in a model of precautionary savings (e.g., Benito, 2006; Carroll et al., 2003). In a similar study, Engen and Gruber (2001) use simulated unemployment benefits to calculate replacement rates and show that the generosity of the unemployment insurance has an impact on savings for the group of employed individuals.

This paper extends the idea of using future unemployment risk in a model of precautionary savings in several ways. First, the simulation comprises three future periods to calculate the uncertainty measure. This way I account for dynamic effects of unemployment in two ways: the model for unemployment controls for true state dependence in the employment status, and the expected future wage is modelled dependent on the previous labour market status. A second contribution of my model is that I explicitly include health as a risk into a model of precautionary savings. To my opinion, health constitutes an important factor for several reasons. To begin with, health plays a major role in determining labour market activity. As a consequence, the financial situation of the individual and the household are also determined by health. In addition, poor health is a risk, about which individuals may have a lot of private information, and it seems straightforward to account for it in the analysis of precautionary savings. As 
labour market risks are affected by poor health and vice-versa, I also have to consider that health and employment may be endogenously determined (e.g. Haan and Myck, 2009). Thus, to account for health risks will improve the identification of labour market related uncertainty. Third, a detailed tax-benefit microsimulation model is applied to calculate the expected income in each scenario, i.e. combinations of being in employment/unemployment and good health/bad health, which constitute the basis to calculate an ex-ante income variance.

Further contributions of this chapter to the literature on savings behaviour are the following: the empirical analysis is conducted using a measure for saving stocks and saving flows. The latter model allows to control for individual specific effects. Moreover, I apply the inverse hyperbolic sine transformation to the wealth aggregate used in the estimation. This is a log-like transformation that allows to keep zero and negative wealth observations in the data. ${ }^{2}$

The next section provides an overview of previous research with a focus on different measures of uncertainty. The following section introduces the estimation models and my approach to model the ex-ante income risk measure. Section 4 presents data, sample and variables. Section 5 shows the results of the simulated uncertainty measure, and Section 6 presents the buffer-stock model and the monthly savings regression. The following section discusses the results and draws several conclusions from the empirical evidence.

2 I discuss health within this chapter in its relation to the employment status. Another interesting research question would be to particularly analyse the relationship of health shocks and precautionary savings. However, this would exceed the scope of my study here. The literature on health risk in the context of precautionary savings is much more focused on the health insurance than on the relation between health, employment and wages. Thus, the focus is on uncertainties about future health care expenditures, which give rise to household savings. In an early simulation, Kotlikoff (1989) showed for the life-cycle model that savings increase if there is uncertainty about medical expenditures (cf. Palumbo, 1999). Hubbard et al. (1995) argues that asset-means tested social insurance programs can prevent low income households from building up assets. Gruber and Yelowitz (1999) test this hypothesis empirically using US data on reforms of the Medicaid program. They find that Medicaid eligibility has a significant negative effect on wealth. In a study for Italy, Jappelli et al. (2007) exploit regional variation in health care quality and show that low quality has a positive effect on precautionary wealth. They conclude that uncertainty about medical expenditures may explain the low dissaving rate of retirees. 


\section{Previous research}

Precautionary savings can be interpreted as a reaction of individuals to insure themselves against (uninsurable) future uncertainty. The resulting precautionary wealth stock is defined as the difference of total wealth holdings to the wealth stock that would be observed if there was no uncertainty (Kimball, 1990). Simulations based on intertemporal models of optimal consumption-savings decisions with income uncertainty show that precautionary wealth may explain a sizeable share of total wealth. For example, Skinner (1988) argues that half of total wealth can be explained by precautionary motives. The studies by Caballero (1991), Gourinchas and Parker (2002), Cagetti (2003) estimate similarly high or even higher shares of precautionary wealth. ${ }^{3}$ However, empirical studies using micro data yield exceptionally diverse results that range from no precautionary wealth (e.g., Dynan, 1993; Skinner, 1988) to large shares of 50 percent and more (e.g., Carroll and Samwick, 1997, 1998; Dardanoni, 1991).

Several methodological and conceptual factors may have contributed to the heterogeneity of empirical results. Table 13 in the Appendix provides an overview of selected empirical studies on precautionary savings. One of the most challenging factors is to model the uncertainty relevant for the study of precautionary savings (Kennickell and Lusardi, 2004). A large number of studies focuses solely on income risk in order to model uncertainty. A common approach is to use some stochastic panel data model of net household income and to derive ex-post variance measures based on this income model (Carroll and Samwick, 1998; Fossen and Rostam-Afschar, 2009; Hubbard et al., 1995;

3 As Carroll and Kimball (2008) note, the results of Gourinchas and Parker (2002) and Cagetti (2003) should be approached with caution. Both studies calibrate a life cycle optimization problem using empirical estimates of income variance and the coefficient of relative risk aversion (CRRA) by Carroll and Samwick (1997). The estimated CRRA depends on the model's assumptions about income uncertainty as faced by the household at the time of the savings decision. Low et al. (2010) show that the estimates by Carroll and Samwick (1997) may overstate the magnitude of shocks to permanent income by as much as 50 percent. They argue that endogenous job mobility choices account for a large proportion of wage fluctuations in Carroll and Samwick (1997). 
Kazarosian, 1997). Others use the variability of expenditures (Dynan, 1993). However, when using this proxy, it may be difficult to distinguish between transitory income and measurement error (Kennickell and Lusardi, 2004). Another aspect is that individuals may already be insured against the estimated income uncertainty (Browning and Lusardi, 1996; Caballero, 1991). Furthermore, these proxies may contain large adjustable elements which increase the variance of earnings but rather reflect choices than uncertainty (Carroll et al., 2003; Guiso et al., 1992; Low et al., 2010).

Important for the present study is a part of the research literature that uses ex-ante risk measures. Some studies use subjective uncertainty indicators in combination with an income simulation. Often these measures show a small variance of income risks, which renders identification difficult. Self-assessed income or employment risks is often measured by categorical variables with few categories. The studies by Guiso et al. (1992) for Italy and Arrondel (2002) for France rely on a very detailed subjective risk assessment of future real household income development. The corresponding income is simulated to construct an income uncertainty measure. Both studies find only small, but significant shares of precautionary wealth - roughly between two and five percent. Lusardi (1997) reestimates the data used in Guiso et al. (1992) with an IV approach and finds a much higher share of precautionary wealth of about 20 to 24 percent.

Using US data, Lusardi (1998) conducts a similar exercise with self-assessed unemployment probabilities, although without simulating household specific replacement rates for this uncertainty measure. Her findings on the share of precautionary wealth are similar to Guiso et al. (1992) and Arrondel (2002) and range from one to 3.5 percent. For Germany, Essig (2005) applies the same uncertainty measure and simulates the respective unemployment replacement rate for the household. However, effects are insignificant.

Another related strand of the literature uses estimated ex-ante indicators. Carroll et al. (2003) simulate unemployment benefits for employed individuals in the US and exploits individual and regional variation in unemployment benefit entitlements. Results 
are mixed and suggest that precautionary savings are income dependent. Whereas low income households do not engage in precautionary savings, evidence can be found for precautionary savings behaviour in higher income groups. However, when housing is excluded from the measure of wealth, the effect of unemployment risk turns insignificant. Although it is plausible to assume that housing equity is part of precautionary wealth, the authors cannot answer the question why no precautionary wealth effect can be found regarding more liquid assets.

Using US data, Engen and Gruber (2001) show that small savings of low income households may be explained by the provision and generosity of unemployment transfers. They regress gross financial wealth on the individual unemployment insurance replacement rate and unemployment risk. One of their findings is that the generosity of the unemployment insurance decreases savings: a ten percent increase in replacement rate would lower savings by 2.8 percent. Benito (2006) uses the probability to become unemployed in the next period to proxy uncertainty with UK data. He uses weekly food consumption as the dependent variable which might influence the comparability of his model with other cited studies. He models uncertainty with an estimated and a subjective measure of future unemployment probability. His results show that a one standard deviation increase in unemployment risk lowers weekly food consumption by 2.7 percent. And he shows that this effect is stronger for younger households. He interprets this result as evidence for a precautionary savings motive. My own results suggest that using the unemployment probability as a measure of income risk might be problematic. Individuals with a high risk of becoming unemployed may also have below average incomes and - with respect to labour market success - disadvantageous characteristics that might drive the results using unemployment risk alone. Instead, it seems important to control whether results change when the same probabilities are used together with a simulation of income in 
each state. ${ }^{4}$

Some studies proxy uncertainty with the occupational status because certain jobs entail higher/lower earnings variance or higher/lower risk of job loss (Fuchs-Schündeln and Schündeln, 2005; Skinner, 1988). Using US data, Skinner (1988) proxies the degree of earnings risks by including dummies for self-employed and farmers in a savings regression. He finds no evidence for precautionary savings. On the contrary, the self-employed as well as farmers appear to save even less than other occupational groups. Lusardi (1997) reports similar findings for Italy. A potential reason is that individuals with different tastes for risk choose different occupations. This would induce a selection effect and bias the estimates downwards. However, it could also be the case that data on saving flows of the self-employed suffer from large measurement error because it may be hard to distinguish between business expenditures from personal consumption (Carroll and Samwick, 1998). Another selection effect results from the fact that we do not observe the self-employed who experienced a negative wealth shock and changed occupation, which would result in a positive bias. Carroll and Samwick (1997, 1998) report that high levels of precautionary savings disappear if the self-employed are excluded from the sample. As Hurst et al. (2010) and Fossen and Rostam-Afschar (2009) point out, this constitutes a problem because the self-employed show higher income uncertainty and higher levels of wealth for other reasons than precautionary motives. Therefore, when including the self-employed in the sample, it is of key importance to properly account for this group. Using data for Germany, Fuchs-Schündeln and Schündeln (2005) solve the problem of self-selection by exploiting a natural experiment in which selection into risk-less occupations is exogenous. They define a risk-less occupation as having a civil servant status (life-time tenure). Using SOEP they find that about 20 percent of all

4 I check the simulated income variance using it as a regressor for subjectively assessed job risks. It turns out that simulated unemployment probabilities are positively correlated with self-assessed job risks but income variance has a negative sign (Section 5.1). 
gross financial and housing wealth in East Germany and 12 percent in West Germany follow a precautionary motive. ${ }^{5}$

For Germany, only a few studies have yet analysed the precautionary savings model and none of these used estimated unemployment probabilities or health risks as a proxy for future uncertainty. Using SOEP data from 2002, Bartzsch $(2006,2008)$ estimates a buffer-stock savings model and applies different measures of income variance to proxy uncertainty. He finds that roughly 20 percent of net financial wealth traces back to the precautionary savings motive. His results suggest that housing equity is not used as a buffer against income shocks. As mentioned above, Fuchs-Schündeln and Schündeln (2005) proxy uncertainty with occupation and find evidence for precautionary savings particularly in East Germany. Using the same data for the years 2002 and 2007, the study by Fossen and Rostam-Afschar (2009) does not find any evidence for precautionary savings. They explicitly account for heterogeneity between entrepreneurial and nonentrepreneurial households and show that the higher savings rate of the self-employed can not be attributed to the precautionary savings motive. They argue that the effect of precautionary savings vanishes once net worth is used as a measure of wealth and that the significant effect on liquid assets could rather reflect portfolio decisions.

Using an error components model, Beznoska and Ochmann (2010) find significant effects of income uncertainty on precautionary savings. In their model, a doubling of transitory income uncertainty increases savings by 4.4 percent or 43 euro for an average household, which is similar to the results of the savings flows regression in this paper. Giavazzi and McMahon (forthcoming) use the pension reform in Germany in 1997 as a quasi-experiment because it was revoked after the elections in 1998 and never came into

5 Their study also reflects the above mentioned large diversity of results. The baseline specification is a linear model with log of gross financial and housing wealth as dependent variable. The model excludes zero or negative wealth observations. As a robustness check, the authors also estimate a tobit specification, in which zero wealth observations were included. From this specification they do not find any precautionary wealth in West Germany and even 68 percent in East Germany. 
force. Their results suggest that the implied increase in income uncertainty increased savings. ${ }^{6}$ Essig (2005) conducted one of the few studies for Germany that is not using SOEP data. Using SAVE, he shows that individuals with negative expectations about the future tend to save less. And he does not find an effect of subjective unemployment probabilities on savings. However, using these expectations might be misleading in the context of precautionary savings. It is very likely that households with negative expectations about the future have also low income and low income variance (see also Section 5.1).

This section has illustrated the diversity of measures of economic uncertainty and has shown how heterogeneous the outcomes of these studies are. In the following, I contribute to the evolving literature by developing an ex-ante measure of economic risks that combines two interdependent labour market risks: future health and unemployment status. My analysis further contributes to the literature by using a detailed microsimulation model to simulate the respective net household income for each potential risk scenario. Moreover, I estimate panel models, whereas most of the aforementioned studies are based on cross-sectional models.

\section{Modelling precautionary savings}

\subsection{Buffer-stock wealth and savings model}

The primary estimation equation follows the literature and models precautionary savings in a buffer-stock wealth model, as suggested by Deaton (1991) and Carroll et al. (1992); Carroll and Samwick $(1997,1998)$. The model is centered around a target wealth-toincome ratio $\frac{W}{P}$. Where $W$ denotes the relevant wealth measure and $P$ the level of

6 They also analyse the labour supply decision and find that household heads who work part-time increase their labour supply in response to the reform. 
permanent income. $\frac{W}{P}$ positively depends on uncertainty, $\sigma$, as faced by the individual. In the steady state, when the target is reached, income uncertainty should have no effect on the savings rate (Carroll and Samwick, 1997). If wealth exceeds or falls below the target, the wealth is expected to fall (dissaving) and to increase (saving), respectively. The importance of the precautionary motive depends on the degree to which wealth increases with uncertainty. In addition, the target ratio may depend on household characteristics $X$ and unobserved factors $\varepsilon$ :

$$
\frac{W}{P}=f(\sigma, X)+\varepsilon
$$

Carroll and Samwick (1998) show that the buffer-stock model predicts an approximately linear relationship between the log of target wealth ratio and the measure of income uncertainty. Permanent income is included as a right hand side variable to allow for non-homothetic preferences:

$$
\log \left(W_{i t}\right)=\alpha+\theta^{w} \log \left(\sigma_{i t}^{2}\right)+\lambda^{w} \log \left(P_{i t}\right)+\beta^{w} X_{i t}+\varepsilon_{i t}
$$

Identification of the relationship in equation (2) is closely related to the chosen measures of wealth, permanent income, and uncertainty. To find an appropriate aggregated wealth measure for the model is difficult. In general, the portfolio elements will differ with respect to their risk and liquidity characteristics (Kennickell and Lusardi, 2004). An illiquid asset cannot serve as a precaution against income shocks. However, it is not obvious what an illiquid asset actually is. Some studies, such as Kazarosian (1997) or Engen and Gruber (2001) have only considered financial wealth, which may however be too restrictive. For example, housing wealth could be pledged as collateral, making that 
asset more liquid. I estimate equation ((2)) using two different wealth measures, net worth (NW) and financial assets (FW). NW includes all wealth components except for business assets, whereas FW is a subset of NW and consists of liquid assets. In particular FW does not include housing equity. If there is a precautionary savings motive, which does not only reflect a portfolio decision, I expect the effect of income uncertainty to be higher for liquid assets but still significant for net worth. Moreover, as described in Section 2, it makes sense to include real estate assets in the wealth measure since previous studies reported strong sensitivity of results if it was included. ${ }^{7}$

If uncertainty has a positive impact on the stock of wealth, it should also increase saving flows. As Guiso et al. (1992) argue, to estimate whether income uncertainty has an effect on asset accumulation and saving flows can be seen as a test of the validity of both models and as two independent tests of the theory of precautionary savings. Therefore, in addition to the buffer-stock model with FW and NW, I estimate a second model using the monthly flow of savings as dependent variable. Carroll and Kimball (2008) emphasize that both concepts, stock and flow values, are easily confused and should be well distinguished. To clarify terminology for the following analysis, I refer to the flow value as "saving" or "savings flows" and to the stock value as "savings" or "wealth". The ad-hoc savings model regresses the log of monthly savings flows $s_{i t}$ on the uncertainty measure $\sigma_{i t}$, permanent income $P_{i t}$, and household characteristics $X_{i t}$ :

$$
\log \left(s_{i t}\right)=\theta^{s} \log \left(\sigma_{i t}^{2}\right)+\lambda^{s} \log \left(P_{i t}\right)+\beta^{\prime s} X_{i t}+u_{i}+e_{i t}
$$

With respect to the measure of permanent income, I use an approach proposed by FuchsSchündeln and Schündeln (2005). In a given year, net household income is detrended

7 For example, the results in Carroll et al. (2003) and Bartzsch (2008) change completely when housing is included in the measure of wealth. 
by dividing it through the average net household income. In a second step, the average detrended net household income for each household is calculated. The product of average annual net household income and the detrended average net household income gives the measure of permanent income. ${ }^{8}$

\section{Quantify precautionary savings}

To approximately quantify the amount of precautionary savings based on the estimated coefficients, a counterfactual simulation is conducted (cf. Carroll and Samwick, 1998). I compare the current savings flows with a situation, in which each household faces the same small income risk $\sigma_{\min }$. The same simulation is done for the buffer-stock wealth model. Estimates of equation $(3)$ are used to predict $\widehat{\log \left(s_{i t}\right)}$ :

$$
\widehat{\log \left(s_{i t}\right)}=\widehat{\theta^{s}} \log \left(\sigma_{i t}^{2}\right)+\widehat{\lambda^{s}} \log \left(P_{i t}\right)+\widehat{\beta^{\prime}} X_{i t}
$$

In the next step, $\log \left(\sigma_{i t}^{2}\right)$ is replaced by $\log \left(\sigma_{\text {min }}^{2}\right)$ and used to predict $\widehat{\log \left(s_{i t}\right)}{ }^{*}$ :

$$
{\widehat{\log \left(s_{i t}\right)}}^{*}=\widehat{\theta^{s}} \log \left(\sigma_{\text {min }}^{2}\right)+\widehat{\lambda^{s}} \log \left(P_{i t}\right)+\widehat{\beta^{s^{\prime}}} X_{i t}
$$

Then $\widehat{\log \left(s_{i t}\right)}{ }^{*}$ is subtracted from $\widehat{\log \left(s_{i t}\right)}$ and divided by $\widehat{\log \left(s_{i t}\right)}$ to obtain a measure of relative change in saving flows if the household faced the (counterfactual) low risk $\sigma_{\text {min }}$. The share of precautionary saving flows in the sample $\overline{P S}^{*}$ is simply the average

8 As a robustness check I calculated a different measure of permanent income as in Bartzsch (2008). The results do not change significantly. 
over this relative difference:

$$
\overline{P S}^{*}=\frac{\frac{1}{N} \sum_{i=1}^{N} \widehat{s}_{i}-\frac{1}{N} \sum_{i=1}^{N} \widehat{s}_{i}^{*}}{\frac{1}{N} \sum_{i=1}^{N} \widehat{s}_{i}}
$$

Previous studies suggested to choose the minimum value of $\sigma$ in the regression sample for $\sigma_{\min }$ (e.g., Carroll and Samwick, 1998). That value is equivalent to a set of household characteristics which implies the lowest uncertainty level in the sample. However, the choice is rather arbitrary and the minimum could strongly depend on outliers. Thus, in addition to the minimum, equation (6) is also evaluated for the first percentile of $\sigma .^{9}$

\subsection{An ex-ante measure of income uncertainty}

The main contribution of this study is the simulation of the ex-ante uncertainty measure $\sigma_{i t}^{2}$. As described above, many studies on precautionary savings use ex-post income variance measures to proxy uncertainty. This approach implies an important assumption: Realized income variations are equivalent to the perceived risk which gives rise to precautionary savings. The advantage of using ex-post data is of course that it can be observed. Moreover, the calculation of different variance measures is straightforward in this case. The disadvantage is however also obvious: this approach uses only realized outcomes to identify the effect of risk expectations on savings behaviour. As precautionary savings are triggered by potential risks that do not have to actually occur, or, as Carroll and Kimball (2008) put it, "precautionary saving result from the knowledge that the future is uncertain", it is straightforward to use counterfactual or different potential outcomes to construct a measure of uncertainty. As a natural alternative to ex-post measured (observed) variance, I propose to use an ex-ante measure of income risk that is

9 As Carroll and Samwick (1998) emphasize, this is a ceteris-paribus simulation. In reality, we would observe general equilibrium effects, particularly on the interest rate. 
constructed from hypothetical (simulated) risk scenarios to explain precautionary savings behaviour.

One of the most important labour market risks for prime age men is unemployment. And the health status is highly related to the employment status. Unemployment has not only an instantaneous effect on income but also a negative impact on reemployment probabilities and future wages. And bad health is strongly associated with unemployment and is likely to affect wages and work capacity negatively. In the precautionary savings model, I follow most of the literature and interpret the labour market risks as exogenous constraints for the individual savings decision. ${ }^{10}$ Both risks are modeled as binary variables. A simulation model is used to assign probabilities to these labour market risks and to simulate respective net household income in each possible state. This approach implies the assumption that individuals perceive uncertainty as income variation conditional on the likelihood that certain income risks may occur. To use the simulation of net household income to build the income variance has the further advantage to enable the simulation of reforms in the tax-benefit system and their impact on precautionary savings.

The combination of health, $h_{i t}$, and labour market status, $l_{i t}$, results in four possible scenarios $s_{i t}$ with:

10 Usually, this assumption is not stated explicitly but of course individuals could react to a change in income variance by changing the employment behaviour as well as the savings behaviour. 


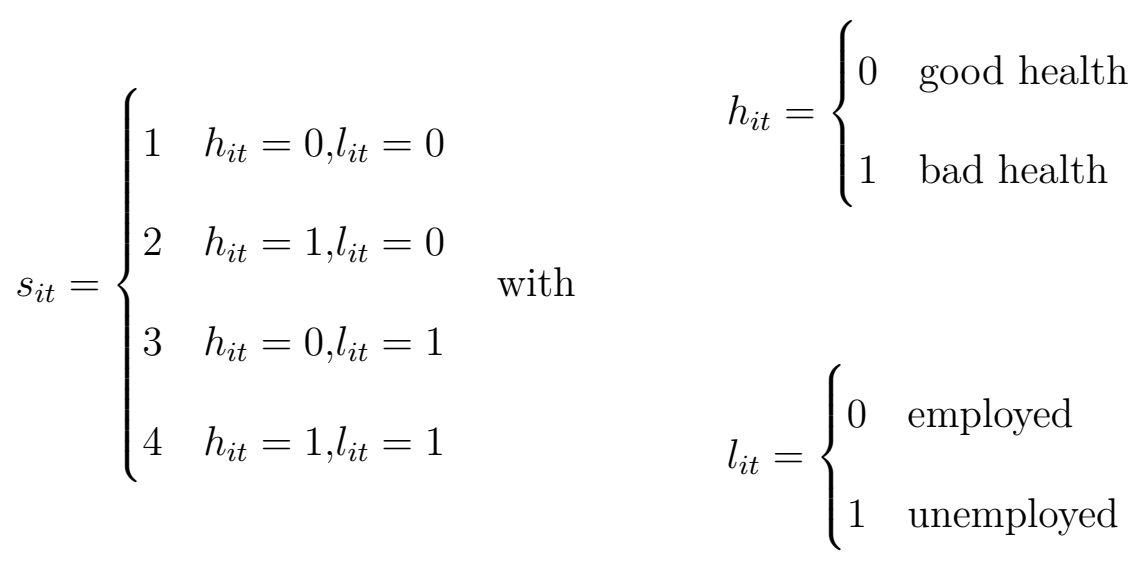

For each scenario $s_{i t}$ I simulate the related income $y_{i t}^{s}$. If $l_{i t}=0$, net income for the scenario when unemployed is calculated, which depends on individual and household characteristics $X_{i t}$ and the tax-benefit function $\gamma_{t}($.$) . If l_{i t}=1$, net income depends on the wage rate $w_{i t}$, hours worked $h_{i t}, X_{i t}$ and $\gamma_{t}($.$) :$

$$
y_{i t}^{s}= \begin{cases}\int \gamma_{t}\left(w_{i t}, h_{i t}, X_{i t}\right) d h_{i t} & \text { if } s=1,2 \\ \gamma_{t}\left(X_{i t}\right) & \text { if } s=3,4\end{cases}
$$

The scenarios are treated as the outcome of a discrete random variable with probability $p_{i t}^{s}$. The expected income over all possible states in period $t$ is the probability weighted predicted income $Y_{i t}$ :

$$
\mathbf{E}\left[y_{i t}\right]=Y_{i t}=p_{i t}^{1} y_{i t}^{1}+p_{i t}^{2} y_{i t}^{2}+p_{i t}^{3} y_{i t}^{3}+p_{i t}^{4} y_{i t}^{4}
$$

And the variance of $y_{i t}$ is given by

$$
\operatorname{Var}\left[y_{i t}\right]=\sigma_{i t}^{2}=p_{i t}^{1}\left(y_{i t}^{1}\right)^{2}+p_{i t}^{2}\left(y_{i t}^{2}\right)^{2}+p_{i t}^{3}\left(y_{i t}^{3}\right)^{2}+p_{i t}^{4}\left(y_{i t}^{4}\right)^{2}-Y_{i t}^{2}
$$


One important feature of the model is that it accounts for path dependency in $l_{i t}$ and $h_{i t}$ by making them dependent on their own lag and the lag of the other variable. Thus, the expected probabilities in $t$ are conditional on being in state $s$ in period $t-1$. For the first period, the state in $t-1$ is known to the individual, whereas it has to be replaced by an expected probability in $t+1$ and $t+2$. Equation (8) and (9) for periods $t+1$ would contain 16 elements and 64 elements for period $t+2$. The variance is calculated over each possible income path and its probability. Moreover, wages also dependent on the lagged labour market and health status. I treat working hours as exogenous and use their observed distribution, differentiated by socio-economic characteristics, to simulate working hours in future periods.

In the following, I explain the steps necessary to construct the uncertainty measure and present the empirical results.

\subsection{Simulation of the uncertainty measure}

\section{Health and employment}

I model health and employment status jointly in a dynamic framework like Haan and Myck (2009). That allows to control for true state dependence and takes into account that unobservable characteristics can have a joint effect on both outcomes. Haan and Myck (2009) find a significant correlation between the two processes and show that it is important to control for state dependence and unobserved heterogeneity. In a similar approach, I specify a bivariate dynamic probit model suggested by (Alessie et al., 2004) and control for the initial conditions as in Wooldridge (2005).

The model is not a simultaneous but rather a sequential intertemporal model. That implies the assumption that the health status in $t$ does not affect the employment status in $t$ and vice versa. The approach avoids the problem of finding exclusion restrictions to identify a simultaneous relationship. Thus, it is not necessary to impose a coherency 
condition to ensure consistency. Both the intertemporal and the simultaneous model require more or less strong assumptions for identification. My strategy can be justified by two arguments: As Haan and Myck (2009) argue, I observe both dependent variables only at the time of the interview, which renders it impossible to determine the exact chronological order of both processes. In addition, due to the inherent state dependence in both employment and health status, the lagged indicators can be interpreted as good proxies of their current status. The following specification will be estimated: ${ }^{11}$

$$
\begin{gathered}
h_{i t}^{*}=h_{i t-1} \gamma_{h}+l_{i t-1} \alpha_{e}+h_{i 0} \delta_{h}+x_{1 i t} \beta_{h}+c_{i}^{h}+\varepsilon_{1 i t} \\
l_{i t}^{*}=l_{i t-1} \gamma_{e}+h_{i t-1} \alpha_{h}+l_{i 0} \delta_{e}+x_{2 i t} \beta_{e}+c_{i}^{l}+\varepsilon_{2 i t} \\
\text { with } m_{i t}^{*}=\left\{\begin{array}{ll}
1 & \text { if } m_{i t}^{*}>0 \\
0 & \text { else }
\end{array}, \quad m:=(l, h)\right.
\end{gathered}
$$

Health and employment status $\left(h_{i t}\right.$ and $\left.l_{i t}\right)$ depend on their own lag, their initial state $\left(h_{i 0}\right.$ and $\left.l_{i 0}\right)$, the lagged indicator of the respective other variable and a set of independent explanatory variables $\left(x_{1 i t}\right.$ and $\left.x_{2 i t}\right)$ which are assumed to be strictly exogenous. The employment equation comprises some independent variables that are not elements of $x_{1 i t}$, the regional unemployment rate, other household income and nationality. All variables in $x_{1 i t}$ are elements of $x_{2 i t}$. In addition, I assume random individual effects $c_{i}^{h}$ and $c_{i}^{l}$ that are bivariate normal with variances $\sigma_{h}^{2}$ and $\sigma_{l}^{2}$ and covariance $\sigma_{h}^{2} \sigma_{l}^{2} \rho_{c}$. The idiosyncratic error terms $\varepsilon_{1 i t}$ and $\varepsilon_{2 i t}$ are assumed to be independent over time and bivariate standard normal with covariance $\rho_{c}$.

11 I use the Stata program GLLAMM to estimate the model. 


\section{Hourly wages}

The simulation of health and employment status results in conditional probabilities of combinations of both states, scenarios $s_{i t}$. The first step to associate these scenarios with income from labour is to model hourly wages. However, the wage itself may depend on previous unemployment and health status. Thus, wages are estimated conditional on the lagged employment and health status. A simplifying assumption of my simulation is that wages only depend on previous unemployment and health. As argued above, both lagged health and employment status are excellent proxies for their current status.

As these effects, in addition to the probabilities, will mainly drive the simulation of income uncertainty, it is important for a valid simulation to estimate the effects of bad health and unemployment on wages consistently. I choose a panel data model suggested by Wooldridge (1995), which simultaneously allows for fixed effects in both the main and the selection equation. Using a within (fixed effects) estimator is particularly useful for our application since unobserved heterogeneity is expected to have an important influence on the wage regression. As long as selection is related to time constant unobserved factors, possible sources for bias due to non-random selection are reduced by using the fixed effects approach. However, selection through time-varying variables could still play a major role. Therefore, I also specify a general selection mechanism that allows for fixed effects. For the wage and the selection equation, the following model is estimated:

$$
\begin{aligned}
& w_{i t}=x_{1 i t} \beta_{x 1}+x_{2 i t} \beta_{x 2}+\mu_{i}+u_{i t} \\
& l_{i t}=\mathbf{1}\left[z_{i t} \gamma+\kappa_{i}+e_{i t}>0\right] \\
& l_{i t} \mid\left(z_{i t}, \kappa_{i}, \mu_{i}\right) \sim N\left(0, \sigma_{l}^{2}\right)
\end{aligned}
$$

In equation (11), $w_{i t}$ denotes the hourly wage rate, the vector of explanatory variables $x_{1 i t}$ refers to characteristics observed regardless of whether being employed or unemployed 
while $x_{2 i t}$ is only observed for the employed. $\mu_{i}$ is an unobserved time-constant individual specific effect, $u_{i t}$ is a time-varying idiosyncratic error. $l_{i t}$ in equation (12) is a selection indicator which equals unity if the expression in the indicator function $\mathbf{1}$ [.] is true. In this application, $x_{1 i t}$ is a subset of $z_{i t}$, which implies that the model is not only identified by functional form. To improve identification, I choose a set of variables that is assumed to influence participation and not the wage rate. The selection equation also contains an individual specific error, $\kappa_{i}$, and a strictly exogenous ${ }^{12}$ normally distributed time varying error $e_{i t}$.

The presence of $\kappa_{i}$ in the non-linear selection equation renders estimation of this selection model difficult. Wooldridge $(1995,2004)$ suggests to use a Mundlak version of Chamberlain's random effects probit model in this case (Chamberlain, 1984; Mundlak, 1978). Let $\bar{z}_{i}$ denote the time average of $z_{i t}$, then $\kappa_{i}$ can be replaced by $\bar{z}_{i} \theta+\omega_{i}$ :

$$
\begin{aligned}
l_{i t} & =\mathbf{1}\left[\bar{z}_{i} \theta+z_{i t} \gamma+v_{i t}>0\right], \quad v_{i t}=\omega_{i}+l_{i t} \\
E\left(\omega_{i} \mid z_{i}\right) & =0 \quad \text { with } \quad x_{i}=\left(x_{1 i}, x_{2 i}, \ldots, x_{T i}\right)
\end{aligned}
$$

A valid correction procedure requires two additional linearity assumptions (Wooldridge, 2004). First, I assume that $u_{i t}$ is mean independent of $\bar{z}_{i}$ conditional on $v_{i t}$ and can be expressed as linear projection onto $v_{i t}$. Second, I specify the conditional mean of the fixed effect in the main equation as a linear projection onto $\left(\bar{x}_{1 i}, \bar{x}_{2 i}, v_{i t}\right)$. Wooldridge's estimator does not impose distributional assumptions about the error terms and the individual effect in the main equation. I estimate the following final specification:

12 Strictly exogenous means that $l_{i t}$ is neither correlated with $\kappa_{i}$ nor with $z_{i t} \forall t$. 


$$
w_{i t}=\bar{x}_{1 i} \xi_{x 1}+x_{1 i t} \beta_{x 1}+\bar{x}_{2 i} \xi_{x 2}+x_{2 i t} \beta_{x 2}+\zeta_{t} \lambda_{i t}+\nu_{i t}
$$

The inverse Mills ratios (IMR), $\lambda_{t}$, are obtained from $t$ cross sectional probit estimations of equation (13). Equation (14) can then be estimated by pooled OLS. A variance that is robust to serial correlation and heteroskedasticity is estimated by a "panel bootstrap" (Semykina and Wooldridge, 2010).

\section{Working hours}

The next step to simulate gross labour income is to generate a distribution of working hours. I simplify the simulation model by assigning the distribution of working hours in period $t$ to the simulated scenarios. To this end, I divide the distribution of working hours into quintiles and generate the corresponding categories. I estimate a multinomial logit that depends on the same set of job characteristics and household variables as hourly wages. Again, the model is estimated separately for East and West Germany. The results are used to predict probabilities for each hours category. Expected hours are calculated by multiplying these probabilities with mean hours of each category and adding them up (results not reported).

\section{Simulation of net household income and income variance}

Net household income is simulated using the Tax-Benefit Microsimulation Model (STSM). This detailed tax-benefit model comprises the main features of the German tax and transfer system. ${ }^{13}$ Net household income is calculated by deducting income tax and social security contributions and by adding individual or household transfers (e.g. child benefits, unemployment benefits and housing benefits).

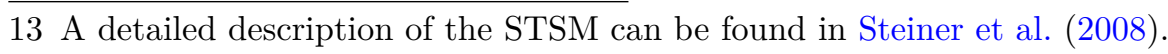


I use the simulated information (probabilities) on labour market status (employed or unemployed), health status (good and bad health), and the respective labour earnings (zero or positive) and keep other household income constant. As described above, I simulate the incomes for different combinations of health and employment status. For the current application, the model simulates net household income three periods ahead. The expected income in period $t$ is given by:

$$
\mathbf{E}\left[y_{i t}\right]=Y_{i t}=\sum_{j=1}^{64} p_{i t}^{j} \times y_{i t}^{j}
$$

To simplify notation, I drop the panel and time indices $(\mathrm{i}, \mathrm{t})$. Instead, let $p_{t+1}^{s, r}$ denote the probability of state $s$ in $t+1$, given state $r$ in period $t$. In addition I assume a discount factor $\pi$ of two percent per year. Any net income $y^{j}$ is then calculated as:

$$
\begin{aligned}
y^{j} & =p_{t+1}^{s, r} \times p_{t+2}^{f, s} \times p_{t+3}^{k, f} \times\left(\pi y_{t+1}^{s, r}+\pi^{2} y_{t+2}^{f, s}+\pi^{3} y_{t+3}^{k, f}\right) \\
r, s, f, k & =1,2,3,4 ; \quad j=1, \ldots, 64
\end{aligned}
$$

Since the state $r$ in period $t$ is known, $64(s \times f \times k)$ possible combinations remain for the calculation of the variance:

$$
\operatorname{Var}\left[y_{i t}\right]=\sigma_{i t}^{2}=\sum_{j=1}^{64} p_{i t}^{j} \times\left(y_{i t}^{j}\right)^{2}-Y_{i t}^{2}
$$

The simulated measure for $\sigma_{i t}^{2}$ is then used in the estimation of equations (2) and (3) and to quantify the share of precautionary savings in total wealth and monthly savings, respectively. 


\section{Data and variables}

The first part of this section briefly describes the estimation sample and variables used in the simulation of $\sigma_{i t}^{2}$. The second part discusses the samples and variables of the main estimation equations in more detail. In addition, using different subjective ex-ante risk assessments, this section comprises an informal test of the simulated income uncertainty measure.

My analysis is based on data from the German Socio-Economic Panel Study (SOEP). ${ }^{14}$ To estimate health and employment probabilities and wages, I use unbalanced panel data covering the period from 1997 until 2009. The sample is restricted to men between 29 and 59 years of age who are not self-employed, not retired, and not in education. To account for the large regional differences in labour market situations, I estimate the models separately for East and West Germany. Table 14 in the Appendix to this chapter provides pooled descriptive statistics for the regression samples of the bivariate probit. The selection equation for the wage model is based on the same sample. For the estimation of wages a subset of working individuals is used (see Table 15 in the Appendix).$^{15}$

The analysis of savings is conducted at the household level. Since the development of the uncertainty measure was restricted to prime age males, I assume the respective individuals to be the household heads. Self-employed respondents are excluded from the analysis since the risks model has only been developed for a sample of dependent employees.

The models on saving flows and buffer stock wealth are estimated for different samples. While data on monthly savings is collected annually in the SOEP, data on household's

14 (See, e.g., Wagner et al., 2007) for more information on SOEP.

15 For the simulation I have to predict wages for individuals whose job characteristics are not observed. I apply the same procedure as described in Geyer and Steiner (2010) and normalise ("orthogonalise") the respective dummies so that setting them equal to zero yields their average effect. The same is done for time dummies. 
financial and non-financial assets was collected only in 2002 and 2007. And the STSM is available for the years 2001 through 2010. Given that the uncertainty measure is built from three future periods, the years 2001 to 2007 remain available for estimation.

The pooled sample statistics for the estimation of saving flows are presented in Table 1. In addition to permanent income and income variance, the model includes age, type of household, unemployment experience, education and regional unemployment. I include unemployment experience to have an additional control variable for past earnings history.

About 66 percent of the samples in both East and West Germany report positive monthly savings. The first model is estimated using log savings as dependent variable and only includes observations with positive savings. As a robustness check I run panel tobit models on the samples, including zero savings observations. In West Germany the average amount of savings is about 360 euro for all observations and 540 euro conditional on positive savings. Savings are about 40 euro lower in East Germany. In the samples of respondents with positive savings, we can find a higher share of higher educated individuals as well as a higher average permanent income and income variance. Moreover, the average unemployment experience is lower in these samples.

The permanent income measure is based on annual net household income which includes, in addition to regular monthly income, components that are paid only once a year or irregularly, like bonuses or vacation pay. Since our sample consists of prime age males, the average permanent income is relatively high and amounts to 43,340 euro in West Germany and to 35,244 euro in East Germany (sample with positive savings).

Table 2 shows the descriptive statistics for the buffer-stock model. I use the same variables as for the saving flows model in the buffer-stock wealth model. In addition, I control for risk attitudes. This information is available for the years 2004 and 2006 . The value of 2004 is used for the data in 2002 and 2006 for 2007 . This is particularly important, since self-selection might be important for the estimated savings reaction to 
Table 1: Saving flows regression: Descriptive statistics by different samples and region

\begin{tabular}{lrrrrr}
\hline & \multicolumn{2}{c}{ West Germany } & & \multicolumn{2}{c}{ East Germany } \\
& sav. $>0$ & all & & sav. $>0$ & \multicolumn{1}{c}{ all } \\
\cline { 2 - 3 } \cline { 5 - 6 } Positive savings & 1.000 & 0.665 & & 1.000 & 0.656 \\
Average savings (monthly) & 538.387 & 358.249 & & 496.845 & 325.752 \\
$\log \left(\sigma^{2}\right)$ & 13.443 & 13.255 & & 12.834 & 12.535 \\
Log permanent income & 10.584 & 10.516 & & 10.368 & 10.261 \\
Permanent income & $43,340.633$ & $40,754.090$ & & $35,244.039$ & $32,128.337$ \\
Age & 46.218 & 46.133 & & 46.478 & 46.461 \\
Type of household: & & & & & \\
Single, no children & 0.139 & 0.141 & & 0.148 & 0.173 \\
Single, children & 0.014 & 0.016 & & 0.024 & 0.030 \\
Couple, no children & 0.289 & 0.269 & & 0.301 & 0.268 \\
Couple, children & 0.505 & 0.517 & & 0.504 & 0.501 \\
Other & 0.053 & 0.058 & & 0.024 & 0.029 \\
Unemployment experience (yrs.) & 0.364 & 0.568 & & 0.623 & 0.984 \\
Years of education: & & & & & \\
7-10.5 & 0.332 & 0.382 & & 0.114 & 0.150 \\
11-12 & 0.299 & 0.297 & & 0.485 & 0.517 \\
12.5+ & 0.369 & 0.320 & & 0.402 & 0.334 \\
Regional unemployment rate & 9.286 & 9.321 & & 18.952 & 18.979 \\
\hline Obs. & 12,557 & 18,871 & & 3,231 & 4,928 \\
\hline
\end{tabular}

Notes: Pooled statistics for years 2001 to 2007.

Source: SOEP, own calculations.

income risk. ${ }^{16}$ Individuals were asked to specify their attitude towards general risk on a eleven-point scale. The items were aggregated to five dummy variables. The buffer-stock model is estimated using all observations since the inverse hyperbolic sine transformation is applied (see Section A in the Appendix ) - a log-like transformation that allows to include observations with zero or negative wealth.

16 For the saving flows model I have enough data to estimate a fixed effects model. For the buffer stock model, the samples are smaller and estimation in first differences resulted in very large standard errors. 
Table 2: Buffer-stock model: Descriptive statistics by region

\begin{tabular}{lcc}
\hline & West Germany & East Germany \\
\hline $\log \left(\sigma^{2}\right)$ & 13.311 & 12.571 \\
Log permanent income & 10.576 & 10.314 \\
Permanent income & $43,399.535$ & $34,053.668$ \\
Risk propensity: & & \\
Very low & 0.087 & 0.072 \\
Low & 0.200 & 0.186 \\
Medium & 0.192 & 0.199 \\
High & 0.256 & 0.271 \\
Very high & 0.113 & 0.089 \\
Age & 46.287 & 46.425 \\
Type of household: & & \\
Single, no children & 0.144 & 0.177 \\
Single, children & 0.014 & 0.034 \\
Couple, no children & 0.271 & 0.271 \\
Couple, children & 0.515 & 0.492 \\
Other & 0.057 & 0.026 \\
Unemployment experience & 0.567 & 1.101 \\
Years of education: & & \\
7-10.5 & 0.357 & 0.144 \\
11-12 & 0.295 & 0.504 \\
12.5+ & 0.348 & 0.351 \\
Regional unemployment rate & 8.706 & 18.292 \\
\hline Obs. & 4,754 & 1,253 \\
\hline
\end{tabular}

Notes: Pooled data for years 2002 and 2007.

Source: SOEP, own calculations.

\subsection{Data on wealth}

SOEP includes a set of detailed questions on private wealth holdings in the years 2002 and 2007. Frick et al. (2007) provide an overview of the wealth data for 2002 and describe how missing information was imputed using Hot-Deck imputation methods in the case of item nonresponse or partial unit non-response. Data are available as five multiple imputed datasets, which has to be taken into account in the subsequent analysis. Therefore, I apply "Rubin's rule" (Rubin, 1987, see Section B in the Appendix to this paper) to all estimated statistics and predictions. 
The wealth module consists of questions on seven components of wealth. These include information on owner-occupied housing (including mortgage debt), other property (including mortgage debt), financial assets, business assets, tangible assets, private pensions (including life insurance) and consumer credits. ${ }^{17}$ The wealth information was collected at the level of the individual. For the subsequent analysis, the wealth components were aggregated to the household level. As explained above, I create two aggregated measures of net wealth that are commonly used in the literature. The first measure, net worth, consists of all wealth components that are available in the SOEP data except for business assets. The second measure is a subset of net worth and refers to liquid assets. Here, I aggregate the information on financial assets, tangible assets, private pensions and consumer credits.

Table 3 shows statistics on financial wealth and net worth. The amount of assets is considerably lower in East Germany, which holds for both financial wealth and net worth. Mean financial wealth is about 37,000 euro in the West and 16,000 euro in East Germany. The definition of net worth adds real estate property (owner-occupied housing and other property) to the financial wealth measure. Average net worth is more than three times higher than financial wealth. The distribution of wealth is highly skewed. For example, the mean is about twice as high as the median for both wealth aggregates and samples. Note that a considerable share of households in the sample does not report to hold positive net liquid assets ( $>20$ percent) or positive net worth ( $>15$ percent). About half of these households are in debt. ${ }^{18}$

For the precautionary savings motive it is interesting to compare wealth holdings with data on income. The median ratio of net liquid assets to permanent income is 0.41 in West and 0.25 in East Germany. Accordingly, the median West (East) German household

17 The data lack information on pension entitlements for workers (statutory pension insurance and company pension plans) and civil servants.

18 Only a negligible fraction of these households holds business assets. 
Table 3: Buffer-stock model: Descriptive statistics on financial wealth and net worth by region

\begin{tabular}{lcccc}
\hline & \multicolumn{2}{c}{ West Germany } & \multicolumn{2}{c}{ East Germany } \\
& FW & NW & FW & NW \\
\hline Mean wealth & 36,923 & 113,794 & 16,373 & 50,741 \\
& $(1,799)$ & $(3,437)$ & $(1,234)$ & $(2,646)$ \\
Median wealth & 15,969 & 63,350 & 8,000 & 25,456 \\
& $(636)$ & $(2,408)$ & $(730)$ & $(2,620)$ \\
Wealth p90 & 90,272 & 274,400 & 47,722 & 133,100 \\
& $(3,035)$ & $(6,888)$ & $(2,843)$ & $(6,525)$ \\
Wealth $>0$ & 0.782 & 0.847 & 0.758 & 0.827 \\
& $(0.007)$ & $(0.006)$ & $(0.013)$ & $(0.012)$ \\
Wealth $=0$ & 0.122 & 0.078 & 0.123 & 0.087 \\
& $(0.005)$ & $(0.004)$ & $(0.010)$ & $(0.008)$ \\
Wealth $<0$ & 0.096 & 0.075 & 0.119 & 0.086 \\
& $(0.005)$ & $(0.004)$ & $(0.010)$ & $(0.009)$ \\
Median ratio: wealth/permanent income & 0.408 & 1.496 & 0.247 & 0.765 \\
& $(0.011)$ & $(0.043)$ & $(0.016)$ & $(0.054)$ \\
Wealth $<$ one month's income & 0.268 & 0.184 & 0.325 & 0.226 \\
& $(0.007)$ & $(0.006)$ & $(0.014)$ & $(0.012)$ \\
\hline Obs. & 4,882 & 4,882 & 1,267 & 1,267 \\
\hline Notes: Standard errors in parentheses. Means and percentiles are estimated & & & & \\
\hline
\end{tabular}

possesses roughly 41 (25) percent of its permanent annual income in net liquid assets. This relation increases markedly when housing equity is included. The low median ratio of liquid assets to permanent income corresponds to the relatively high share of 26 and 33 percent of households which hold liquid assets of less than one month's income in West and East Germany, respectively. This number is strongly reduced when housing equity is included but still characterises about one fifth of the samples. 


\section{Results of simulated income uncertainty}

Table 4 shows the estimated coefficients of equation (10). I find similar qualitative results as Haan and Myck (2009). There is a strong dependence between both processes. On the one hand, I can find significant effects of the lagged variables of the respective other process, and, on the other hand, I can also find a significant correlation between the random effects. In addition, results provide strong support for state dependence in health and employment status.

Table 4: Regression results for the bivariate random effects probit by region

\begin{tabular}{|c|c|c|c|c|c|c|c|c|}
\hline \multirow[b]{3}{*}{ Lagged health status } & \multicolumn{4}{|c|}{ West Germany } & \multicolumn{4}{|c|}{ East Germany } \\
\hline & \multicolumn{2}{|c|}{ Bad health } & \multicolumn{2}{|c|}{ Unemployment } & \multicolumn{2}{|c|}{ Bad health } & \multicolumn{2}{|c|}{ Unemployment } \\
\hline & $1.281^{* *}$ & $(0.026)$ & $0.403^{* *}$ & $(0.038)$ & $1.383^{* *}$ & $(0.046)$ & $0.346^{* *}$ & $(0.057)$ \\
\hline Lagged employment status & $0.218^{* *}$ & $(0.031)$ & $1.680^{* *}$ & $(0.037)$ & $0.282^{* *}$ & $(0.046)$ & $1.371^{* *}$ & $(0.045)$ \\
\hline Age & -0.182 & $(0.113)$ & $0.660^{* *}$ & $(0.142)$ & -0.113 & $(0.213)$ & $0.614^{* *}$ & $(0.201)$ \\
\hline $\mathrm{Age}^{2} / 100$ & $0.491^{\dagger}$ & $(0.254)$ & $-1.690^{* *}$ & $(0.320)$ & 0.343 & $(0.475)$ & $-1.500^{* *}$ & $(0.455)$ \\
\hline $\mathrm{Age}^{3} / 100$ & $-0.004^{*}$ & $(0.002)$ & $0.014^{* *}$ & $(0.002)$ & -0.003 & $(0.003)$ & $0.012^{* *}$ & $(0.003)$ \\
\hline Years of education (ref. 11-12): & & & & & & & & \\
\hline $7-10.5$ & $0.076^{* *}$ & $(0.024)$ & $0.211^{* *}$ & $(0.033)$ & 0.046 & $(0.048)$ & $0.189^{* *}$ & $(0.047)$ \\
\hline $12.5+$ & $-0.145^{* *}$ & $(0.029)$ & $-0.131^{* *}$ & $(0.041)$ & $-0.149^{* *}$ & $(0.047)$ & $-0.324^{* *}$ & $(0.049)$ \\
\hline Initial health status & $0.636^{* *}$ & $(0.030)$ & $0.173^{* *}$ & $(0.044)$ & $0.551^{* *}$ & $(0.053)$ & $0.126^{\dagger}$ & $(0.065)$ \\
\hline Initial employment experience & $-0.007^{*}$ & $(0.003)$ & $-0.010^{* *}$ & $(0.004)$ & -0.002 & $(0.006)$ & -0.004 & $(0.006)$ \\
\hline Initial employment status & $0.028^{* *}$ & $(0.007)$ & $0.068^{* *}$ & $(0.008)$ & $0.033^{*}$ & $(0.016)$ & $0.183^{* *}$ & $(0.016)$ \\
\hline Person in $\mathrm{HH}$ needs care & $0.160^{* *}$ & $(0.061)$ & $0.342^{* *}$ & $(0.076)$ & 0.096 & $(0.094)$ & $0.210^{\dagger}$ & $(0.110)$ \\
\hline Foreign nationality & & & $0.198^{* *}$ & $(0.037)$ & & & 0.067 & $(0.274)$ \\
\hline Type of household (ref. Single): & & & & & & & & \\
\hline Single, children & & & $-0.337^{* *}$ & $(0.081)$ & & & -0.116 & $(0.111)$ \\
\hline Couple, no children & & & $-0.561^{* *}$ & $(0.050)$ & & & $-0.444^{* *}$ & $(0.069)$ \\
\hline Couple, children & & & $-0.542^{* *}$ & $(0.046)$ & & & $-0.546^{* *}$ & $(0.063)$ \\
\hline Other & & & $-0.329^{* *}$ & $(0.068)$ & & & $-0.388^{* *}$ & $(0.116)$ \\
\hline Regional unemployment rate & & & $0.029^{* *}$ & $(0.004)$ & & & $0.016^{\dagger}$ & $(0.008)$ \\
\hline Other $\mathrm{HH}$ income & & & $-1.480^{* *}$ & $(0.051)$ & & & $-1.260^{* *}$ & $(0.069)$ \\
\hline Constant & 0.329 & $(1.650)$ & $-9.238^{* *}$ & $(2.056)$ & -0.900 & $(3.113)$ & $-8.856^{* *}$ & $(2.917)$ \\
\hline Year dummies & Yes & & Yes & & Yes & & Yes & \\
\hline$\sigma$ & 1.437 & $(0.121)$ & 1.312 & $(0.209)$ & 1.253 & $(0.113)$ & 1.192 & $(0.092)$ \\
\hline$\rho_{c}$ & 0.528 & $(0.041)$ & & & 0.612 & $(0.042)$ & & \\
\hline$\rho_{\varepsilon}$ & 0.183 & $(0.030)$ & & & 0.172 & $(0.024)$ & & \\
\hline Obs. & 32,719 & & & & 10,485 & & & \\
\hline
\end{tabular}

The other covariates have the expected signs. With the exception of the age profile, the effects of all other covariates that appear in both equations have the same sign. For example, higher education reduces the risk of both unemployment and poor health. In contrast to Haan and Myck (2009), I only find a low effect of the regional unemployment rate. This can be explained by two factors: first, I include time dummies. The regional 
unemployment rate in the model of Haan and Myck (2009) is in fact an interaction with a time dummy. Second, Haan and Myck (2009) do not distinguish between East and West Germany. Thus, the regional unemployment rate also contains information about the differences in the level of unemployment between East and West Germany.

In order to assess the magnitude of the effects and to compare them between both regional subsamples, Table 5 presents simulated probabilities for an individual with average characteristics. The results are simulated for different values of the lagged health and employment status. The table shows the respective transition probabilities. The largest state dependence is found for being in good health and employment $\left(s_{i t}=1\right)$. It amounts to 90 percent in West Germany and to a lower 86 percent in East Germany. For this category, the probability to become unemployed in period $t$ is nearly ten percent in East Germany and only 3.5 percent in West Germany. Lagged poor health increases the probability to become unemployed for West Germany to more than seven percent and to about 15 percent in East Germany. The state dependence in unemployment for healthy individuals is higher in East Germany (roughly 50 percent compared to 40 percent in West Germany). The least regional differences are found for the status being in poor health and unemployment.

These results clearly show the importance of health for the risk of unemployment. In the simulation, I assume that the estimated coefficients remain stable and that household

Table 5: Predicted transition probabilities of employment and health status by region

\begin{tabular}{|c|c|c|c|c|c|c|c|c|}
\hline & \multicolumn{4}{|c|}{ West Germany } & \multicolumn{4}{|c|}{ East Germany } \\
\hline & $s_{i, t}=1$ & $s_{i, t}=2$ & $s_{i, t}=3$ & $s_{i, t-1}=4$ & $s_{i, t}=1$ & $s_{i, t}=2$ & $s_{i, t}=3$ & $s_{i, t-1}=4$ \\
\hline$s_{i, t-1}=1$ & 90.1 & 6.4 & 3.0 & 0.5 & 85.7 & 4.9 & 8.4 & 1.0 \\
\hline$s_{i, t-1}=2$ & 56.1 & 36.4 & 3.2 & 4.2 & 51.1 & 32.7 & 7.6 & 8.6 \\
\hline$s_{i, t-1}=3$ & 55.5 & 4.7 & 34.3 & 5.6 & 46.3 & 3.6 & 43.9 & 6.3 \\
\hline$s_{i, t-1}=4$ & 26.4 & 19.0 & 24.4 & 30.1 & 20.7 & 16.4 & 27.3 & 35.7 \\
\hline \multicolumn{9}{|c|}{$\begin{array}{l}\text { Notes: The probabilities are simulated for an average individual in the regression sample. Rows sum up to } 100 \\
\text { percent, deviations are due to rounding erros. See page } 17 \text { for the definition of } s_{i t} \text {. }\end{array}$} \\
\hline
\end{tabular}


composition does not change over the next periods. The year effects are orthogonalized to the mean value and are set to zero. Other household income is assumed to grow at a rate of two percent. ${ }^{19}$

Table 6 shows the estimated coefficients of the wage regression using three different estimation methods (OLS, FE, FEsel) for West and East Germany. "FEsel" denotes Wooldridge's 1995 estimator.

A Hausman test rejects the null hypothesis of no correlation with the individual fixed effect at any conventional significance level for both samples. Furthermore, the IMRs are jointly significant for both samples. ${ }^{20}$ Thus, the preferred specification is FEsel. ${ }^{21}$

For the simulation, I focus on the effects of lagged health and employment status. Lagged poor health reduces wages by five percent in the OLS model for West Germany. Controlling for fixed effects, the point estimate remains negative but becomes smaller and insignificant. The effect is very small and insignificant across all specifications for East Germany. Thus, there is only a negligible negative direct health effect on hourly wages. $^{22}$

Lagged unemployment also has a negative effect on wages but its magnitude is larger and, at least for the West German sample, remains significant in all specifications. The OLS model suggests a reduction of hourly wages by about 29 percent in the West and 17 percent in East Germany. This very large estimate is likely to be upward biased. Using the fixed effects model, it is still significant but reduced to twelve (West) and five (East)

19 This is a gross value and not affected by the simulation if I assume constant behaviour of the other household members.

20 A preliminary test with a simple selection indicator (Wooldridge, 2004) rejected the null hypothesis that no selection bias is present (not reported).

21 I report standard OLS and FE results for comparison.

22 This result differs from the findings in Jäckle and Himmler (2010). Using the SOEP, Jäckle and Himmler (2010) estimate a similar wage model with health satisfaction instead of general health status. They find a negative effect of deteriorated health for men but do not focus on the effects of unemployment in their model. They estimate a small significant effect of health on wages using the same estimator. However, the models are not strictly comparable since samples, time window and regressors, in particular the used health measure, are different. 
percent respectively. In addition, when selection is accounted for, the effect is further reduced to two percent and gets insignificant in East Germany. In West Germany, it has a significant negative effect of 7.3 percent.

Table 6: Wage regression

\begin{tabular}{|c|c|c|c|c|c|c|}
\hline & \multicolumn{3}{|c|}{ West Germany } & \multicolumn{3}{|c|}{ East Germany } \\
\hline & OLS & $\mathrm{FE}$ & FEsel & OLS & $\mathrm{FE}$ & FEsel \\
\hline Lagged health status & $\begin{array}{c}-0.050^{* *} \\
(0.006)\end{array}$ & $\begin{array}{r}-0.009 \\
(0.006)\end{array}$ & $\begin{array}{r}-0.002 \\
(0.006)\end{array}$ & $\begin{array}{r}-0.016 \\
(0.016)\end{array}$ & $\begin{array}{r}-0.006 \\
(0.016)\end{array}$ & $\begin{array}{r}-0.005 \\
(0.023)\end{array}$ \\
\hline Lagged employment status & $\begin{array}{c}-0.286^{* *} \\
(0.021)\end{array}$ & $\begin{array}{c}-0.123^{* *} \\
(0.020)\end{array}$ & $\begin{array}{c}-0.073^{* *} \\
(0.010)\end{array}$ & $\begin{array}{c}-0.165^{* *} \\
(0.024)\end{array}$ & $\begin{array}{r}-0.050^{*} \\
(0.023)\end{array}$ & $\begin{array}{r}-0.019 \\
(0.013)\end{array}$ \\
\hline Age & $\begin{array}{l}0.049^{* *} \\
(0.019)\end{array}$ & & & $\begin{array}{l}0.174^{* *} \\
(0.036)\end{array}$ & & \\
\hline $\operatorname{Age}^{2} / 100$ & $\begin{array}{r}-0.065 \\
(0.042)\end{array}$ & $\begin{array}{r}-0.022 \\
(0.055)\end{array}$ & $\begin{array}{c}-0.192^{* *} \\
(0.024)\end{array}$ & $\begin{array}{c}-0.358^{* *} \\
(0.081)\end{array}$ & $\begin{array}{r}-0.217^{*} \\
(0.107)\end{array}$ & $\begin{array}{c}-0.329^{* *} \\
(0.077)\end{array}$ \\
\hline $\mathrm{Age}^{3} / 100$ & $\begin{array}{c}0.000 \\
(0.000)\end{array}$ & $\begin{array}{r}-0.000 \\
(0.000)\end{array}$ & $\begin{array}{l}0.001^{* *} \\
(0.000)\end{array}$ & $\begin{array}{l}0.002^{* *} \\
(0.001)\end{array}$ & $\begin{array}{r}0.001^{\dagger} \\
(0.001)\end{array}$ & $\begin{array}{l}0.002^{* *} \\
(0.001)\end{array}$ \\
\hline \multicolumn{7}{|l|}{ Years of education (ref. 11-12): } \\
\hline $7-10.5$ & $\begin{array}{c}-0.020^{* *} \\
(0.005)\end{array}$ & $\begin{array}{r}-0.005 \\
(0.013)\end{array}$ & $\begin{array}{r}-0.000 \\
(0.020)\end{array}$ & $\begin{array}{r}-0.014 \\
(0.012)\end{array}$ & $\begin{array}{r}-0.005 \\
(0.032)\end{array}$ & $\begin{array}{c}0.004 \\
(0.048)\end{array}$ \\
\hline $12.5+$ & $\begin{array}{l}0.116^{* *} \\
(0.006)\end{array}$ & $\begin{array}{c}0.022 \\
(0.026)\end{array}$ & $\begin{array}{c}0.021 \\
(0.033)\end{array}$ & $\begin{array}{l}0.100^{* *} \\
(0.013)\end{array}$ & $\begin{array}{c}0.027 \\
(0.053)\end{array}$ & $\begin{array}{c}0.036 \\
(0.031)\end{array}$ \\
\hline Regional unemployment rate & $\begin{array}{c}-0.008^{* *} \\
(0.001)\end{array}$ & $\begin{array}{r}-0.003 \\
(0.003)\end{array}$ & $\begin{array}{l}0.008^{*} \\
(0.004)\end{array}$ & $\begin{array}{r}-0.001 \\
(0.002)\end{array}$ & $\begin{array}{r}-0.001 \\
(0.006)\end{array}$ & $\begin{array}{c}0.017 \\
(0.011)\end{array}$ \\
\hline $\begin{array}{l}\mathrm{IMR} \\
\chi_{11}^{2}\end{array}$ & No & No & $\begin{array}{c}\text { Yes } \\
96.04^{* *}\end{array}$ & No & No & $\begin{array}{c}\text { Yes } \\
47.92^{* *}\end{array}$ \\
\hline $\begin{array}{l}\text { Mundlak terms } \\
\chi_{39}^{2}\end{array}$ & No & No & $\begin{array}{c}\text { Yes } \\
1,559.38^{* *}\end{array}$ & No & No & $\begin{array}{c}\text { Yes } \\
575.36^{* *}\end{array}$ \\
\hline Year dummies & Yes & Yes & Yes & Yes & Yes & Yes \\
\hline Industry dummies & Yes & Yes & Yes & Yes & Yes & Yes \\
\hline Occupation dummies & Yes & Yes & Yes & Yes & Yes & Yes \\
\hline Firm size dummies & Yes & Yes & Yes & Yes & Yes & Yes \\
\hline Hausman test (p-value) & & 0.00 & & & 0.00 & \\
\hline No. of groups & & 5,699 & & & 1,669 & \\
\hline Obs. & 30,155 & 30,155 & 30,155 & 8,620 & 8,620 & 8,620 \\
\hline
\end{tabular}

In order to illustrate the economic significance of the findings in Table 6, I simulate 
wages for an individual with average characteristics. ${ }^{23}$ Similar to the simulation for health and employment status, I vary the simulation by lagged health and employment status. Table 7 shows the simulated wage levels.

Table 7: Wage level predictions by lagged employment and health status and region (different regression models)

\begin{tabular}{lccccccc}
\hline & \multicolumn{3}{c}{ West Germany } & & \multicolumn{3}{c}{ East Germany } \\
& OLS & FE & FEsel & & OLS & FE & FEsel \\
\cline { 2 - 4 } \cline { 6 - 8 }$s_{i, t-1}=1$ & 16.90 & 16.25 & 15.77 & & 11.34 & 10.77 & 10.71 \\
$s_{i, t-1}=2$ & 16.07 & 16.10 & 15.74 & & 11.16 & 10.70 & 10.70 \\
$s_{i, t-1}=3$ & 12.70 & 14.37 & 14.44 & & 9.57 & 10.24 & 10.38 \\
$s_{i, t-1}=4$ & 12.07 & 14.24 & 14.41 & & 9.42 & 10.18 & 10.38 \\
\hline
\end{tabular}

Notes: Wages are evaluated for an individual with average characteristics. See page 17 for the definition of $s_{i t}$.

Source: SOEP, own calculations.

For an average man who was employed and in good health in the previous period $\left(s_{i, t-1}=1\right)$, the average hourly wage rate is nearly seven euro higher compared to someone who was unemployed and in bad health $\left(s_{i, t-1}=4\right)$ in the West German sample. This difference turns out to be smaller in East Germany and amounts to less than two euro. The coefficients are smaller in the fixed effects approach. For West Germany, the difference decreases to two euro and to less than one euro in East Germany. A selection correction reduces the effect even further, to about 1.3 euro in the West and 0.3 euro in East Germany. The differences in wages between $\left(s_{i, t-1}=1\right)$ and $\left(s_{i, t-1}=2\right)$ and between $\left(s_{i, t-1}=3\right)$ and $\left(s_{i, t-1}=4\right)$ are negligible due to the low estimated coefficient of lagged health status.

Distributions of the variances by health status and region are depicted in Figure 1. The horizontal lines represent the mean variance. Figure 1a shows a higher income variance in West Germany as compared to East Germany, which is presumably related to the

23 Year effects, industry, occupation and firm size dummies are orthogonalized to their mean effect. I set these categorial dummies to zero in the simulation of future wages of currently unemployed individuals. 
higher income level. However, differences between East and West Germany are smaller than between individuals in bad and good health. Figure 1b shows that the simulated variance for individuals in good health is higher than for those in bad health. Figures $1 \mathrm{c}$ and 1d demonstrate that this difference is similar in East and West Germany.

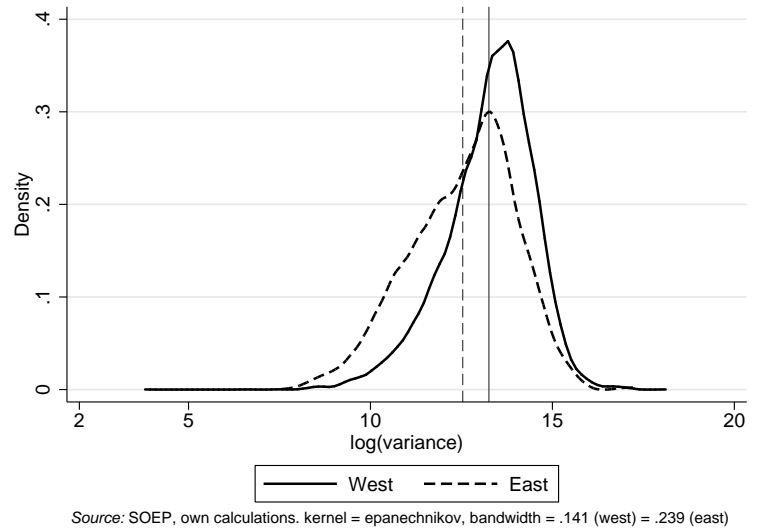

(a) Region

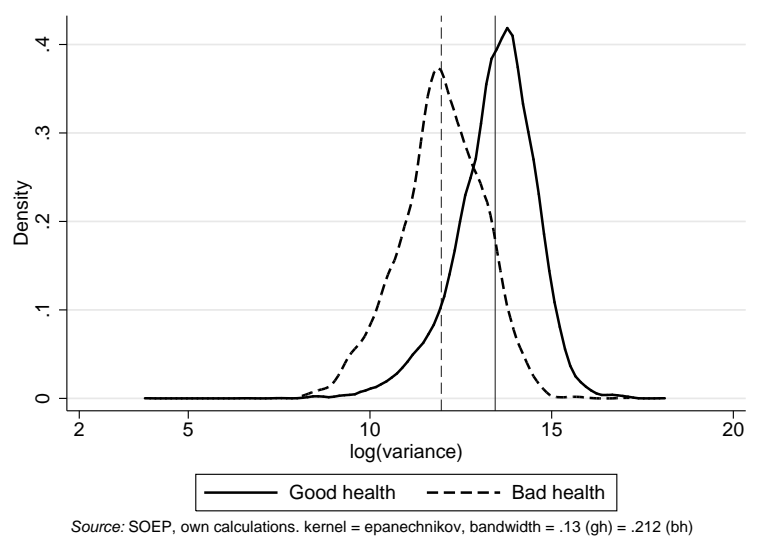

(c) West Germany

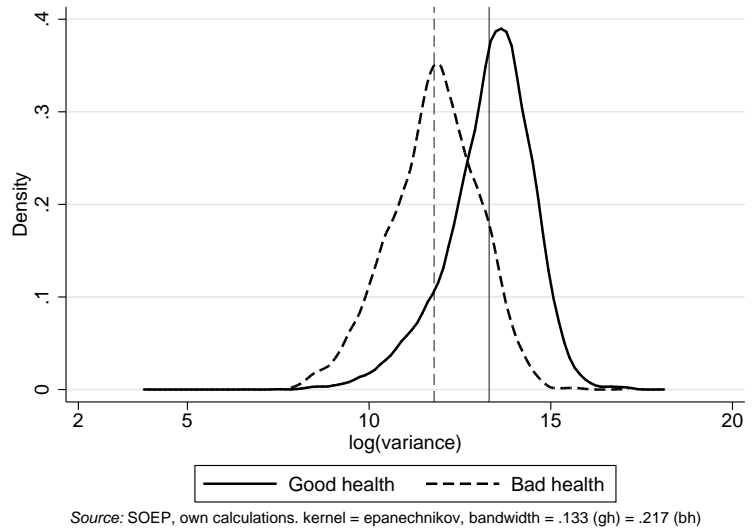

(b) Health

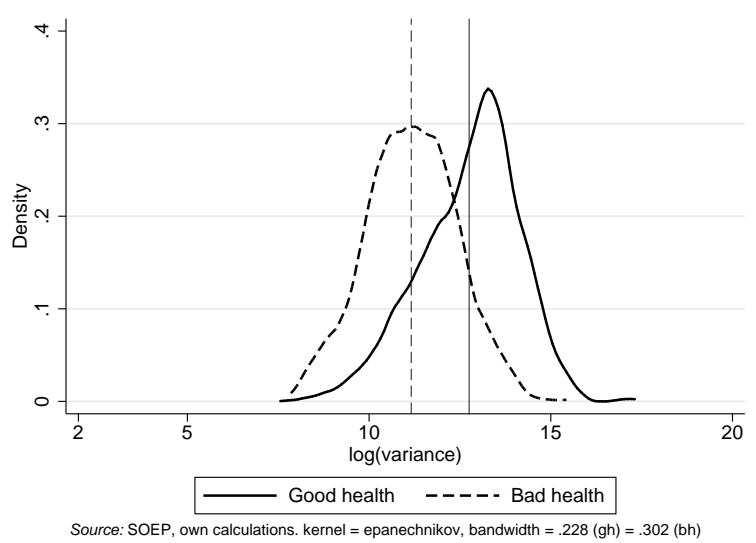

(d) East Germany

Figure 1: Kernel densities of net household income variance by region and health status

As expected, individuals with higher incomes or lower economic risks (good health vs. bad health or West vs. East Germany) have a higher income variance. This is important to keep in mind when I now turn to the savings model. Precautionary savings should not be simply identified with low income households. In fact, the motive seems particularly relevant for household which can loose much - in a relative sense - but with 
a low probability of occurrence.

\subsection{Simulated uncertainty and subjective risk assessment}

A simple test of the simulated uncertainty measure is to relate it to subjective risk assessments and to test whether both measures are significantly correlated and in what direction. Two variables from SOEP are chosen: (1) worries about job security (threepoint scale) and (2) how likely it is for the respondent to lose his/her job within the next two years (in percent).

The first item is available for all years, whereas the second is asked only every other year. The three-point scale is dichotomized to " $1=$ has worries" and " $0=$ no worries" and a probit model is estimated. The second variable has a continuous scale and is estimated using OLS. The subjective indicators are regressed on the same set of variables as in the savings regression (Section 6.2, equation (4)). The only exception is that, in addition to income variance, I regress the indicators on simulated employment and health probabilities (only for period $t+1$ ). The probabilities add up to one, and a reference category has to be defined. Here it is the probability to be in good health and employed in the next period.

Table 8 shows the regression results. The probabilities and income uncertainty are significant in nearly all models. The estimates reveal an interesting differentiation of the uncertainty measure. Note that the questions about job security and worries are asked conditional on being employed. First of all, negative expectations about job security in the probit and OLS models are negatively correlated with simulated income variance and

permanent income. Secondly, the set of probabilities have positive signs. For example, an estimated coefficient of 28.8 in the OLS model (2) for West Germany implies c.p. that an increase of one percentage point in the simulated probability to be unemployed in the next period increases the subjective probability to become unemployed within the next 


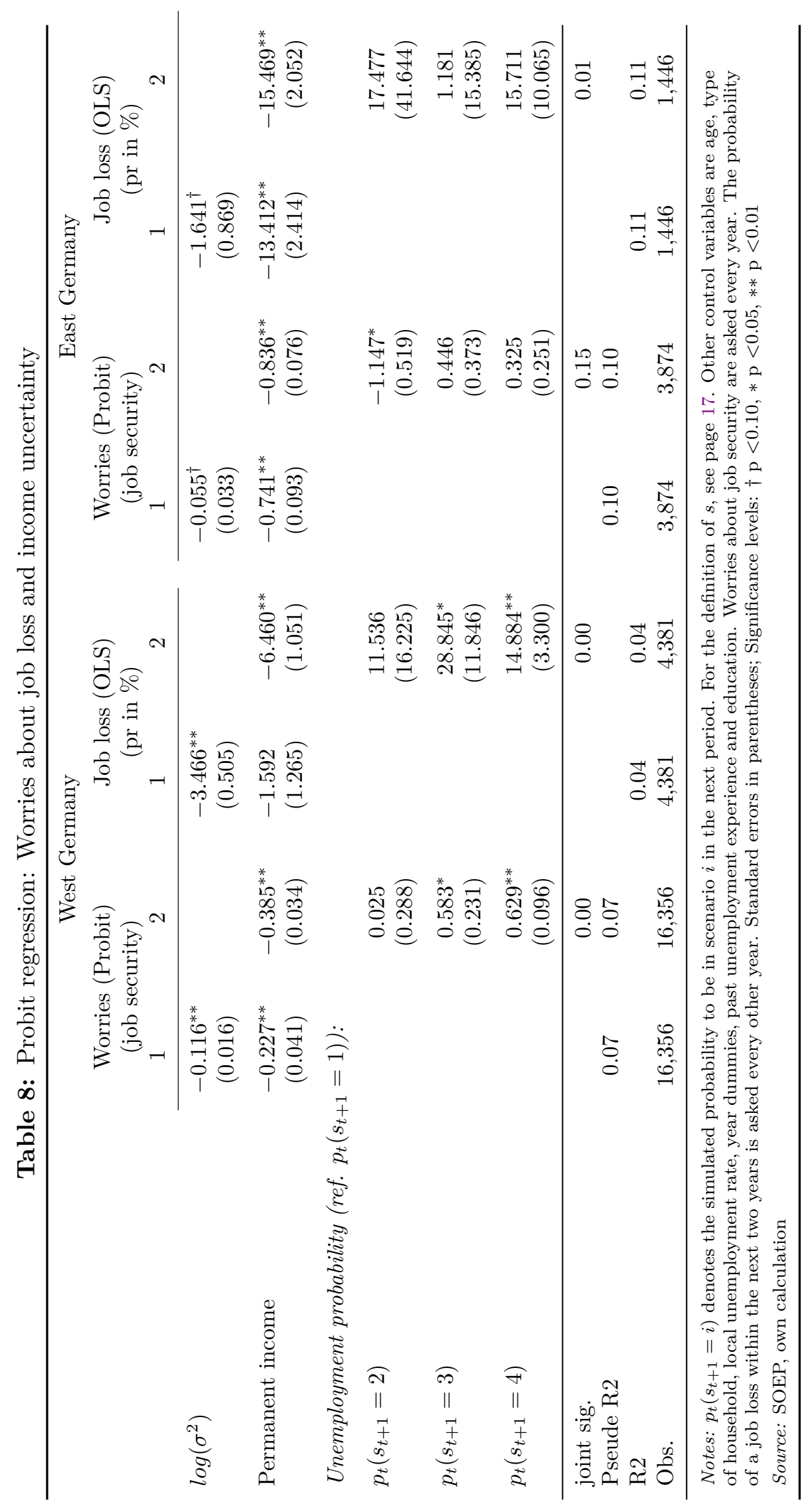




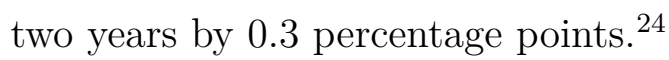

This result shows that uncertainty measured by unemployment probabilities and measured by income variance cannot simply be interpreted in the same way, as if measuring the same concept of uncertainty. In general, higher income is associated with more stable employment biographies and vice versa. Thus, it is not surprising that studies on precautionary savings often find that negative subjective expectations are negatively correlated with savings (e.g., Essig, 2005). However, this is no evidence against the precautionary savings motive but rather shows that individuals who assess their future negatively often have no resources or motivation to save. Thus, for a precautionary savings model, it is important to associate the unemployment/employment probabilities with income. Individuals who face a low risk of becoming unemployed may have a good reason and resources to save as a precaution for this unlikely event.

\section{Multivariate analysis of precautionary savings}

In the first part of this section, the estimates for the regression of savings flows on the simulated income uncertainty according to equation (3) are presented. Results for the buffer-stock model (equation (2)) are shown in the second part.

\subsection{Buffer-stock wealth}

As described above, a considerable share of the sample shows no or negative wealth accumulation. In order to keep these observations (and their information) in the sample, the inverse hyperbolic sine (IHS) transformation is applied to the wealth aggregates. The Appendix to this paper (Section A provides more details on the transformation.

24 Note that this effect has to be interpreted with respect to the reference category. Thus, the increase of one percentage point is c.p. equivalent to a decrease of one percentage point in the reference category. 
Tables 9 and 10 report estimated marginal effects for West Germany and East Germany, respectively. The estimated coefficients are reported in the Appendix. Marginal effects are evaluated at the median wealth level. The column with percentage-changes is an approximation for larger values of the dependent variable.

For West Germany, the effect of income uncertainty is significantly positive for both financial wealth and net worth. A doubling of log variance increases financial wealth by 965 euro or roughly five percent. The magnitude of the absolute effect increases to 3,734 euro when net worth is the dependent variable but the relative effect of 5.7 percent remains similar. The estimation is robust to the chosen wealth aggregate. This is the first important finding, since, as noted above, many studies report unstable results for different definitions of wealth. This is also visible when the share of precautionary wealth is considered. Evaluated at the minimum risk, it amounts to 30 and 35 percent for $\mathrm{FW}$ and NW, respectively. At the first percentile, the estimates drop to 17 and 14 percent. Thus, another important finding is that the magnitude of the share of precautionary wealth is similar to the findings with respect to precautionary saving. And finally, the share of precautionary wealth drops slightly when housing equity is included in the wealth aggregate. Since it does not decrease proportionally - as shown above, the average share of housing equity exceeds the share of financial wealth in NW - a part of housing equity must serve a precautionary purpose.

Findings are less consistent for East Germany than for the West German sample. The estimated coefficients of income risk are positive but not significant and higher in the model with net worth as dependent variable. Consequently, I can find a higher share of precautionary wealth when housing equity is included in the wealth aggregate. This means that East Germans have relatively more precautionary wealth in real estate assets than in financial wealth. This is a counterintuitive finding, which requires further analysis. A potential reason is the small sample. In particular the results for FW seem to be inconsistent with the findings on precautionary saving and the model for NW. Although 
Table 9: Wealth regression, West Germany - marginal effects

\begin{tabular}{|c|c|c|c|c|}
\hline & \multicolumn{2}{|c|}{ Financial wealth } & \multicolumn{2}{|c|}{ Net worth } \\
\hline & Marginal effect & $\%$-change & Marginal effect & $\%$-change \\
\hline $\log \left(\sigma^{2}\right)$ & $\begin{array}{c}965.297^{*} \\
(475.423)\end{array}$ & $\begin{array}{c}0.053^{*} \\
(0.026)\end{array}$ & $\begin{array}{c}3,734.480^{*} \\
(1,590.736)\end{array}$ & $\begin{array}{c}0.057^{*} \\
(0.024)\end{array}$ \\
\hline Log permanent income & $\begin{array}{l}17,314.563^{* *} \\
(1,425.630)\end{array}$ & $\begin{array}{c}0.956^{* *} \\
(0.079)\end{array}$ & $\begin{array}{l}68,520.283^{* *} \\
(4,615.948)\end{array}$ & $\begin{array}{l}1.039^{* *} \\
(0.070)\end{array}$ \\
\hline Age & $\begin{array}{c}2,808.429 \\
(2,784.322)\end{array}$ & $\begin{array}{c}0.155 \\
(0.154)\end{array}$ & $\begin{array}{l}26,169.784^{* *} \\
(9,513.399)\end{array}$ & $\begin{array}{l}0.397^{* *} \\
(0.144)\end{array}$ \\
\hline $\mathrm{Age}^{2} / 100$ & $\begin{array}{c}-4,531.201 \\
(6,215.466)\end{array}$ & $\begin{array}{r}-0.250 \\
(0.343)\end{array}$ & $\begin{array}{r}-49,185.020^{*} \\
(21,282.938)\end{array}$ & $\begin{array}{r}-0.746^{*} \\
(0.323)\end{array}$ \\
\hline $\mathrm{Age}^{3} / 100$ & $\begin{array}{c}27.833 \\
(45.238)\end{array}$ & $\begin{array}{c}0.002 \\
(0.002)\end{array}$ & $\begin{array}{r}337.908^{*} \\
(155.223)\end{array}$ & $\begin{array}{c}0.005^{*} \\
(0.002)\end{array}$ \\
\hline Single, children & $\begin{array}{c}-15,346.669^{* *} \\
(3.645 .737)\end{array}$ & $\begin{array}{c}-0.847^{* *} \\
(0.202)\end{array}$ & $\begin{array}{c}-38,998.420^{* *} \\
(12.928 .130)\end{array}$ & $\begin{array}{c}-0.591^{* *} \\
(0.196)\end{array}$ \\
\hline Couple, no children & $\begin{array}{c}-7,164.548^{* *} \\
(1,262.459)\end{array}$ & $\begin{array}{c}-0.396^{* *} \\
(0.069)\end{array}$ & $\begin{array}{c}-19,485.114^{* *} \\
(4,227.795)\end{array}$ & $\begin{array}{c}-0.295^{* *} \\
(0.064)\end{array}$ \\
\hline Couple, children & $\begin{array}{c}-11,184.692^{* *} \\
(1,205.271)\end{array}$ & $\begin{array}{c}-0.618^{* *} \\
(0.067)\end{array}$ & $\begin{array}{c}-20,329.480^{* *} \\
(4092.110)\end{array}$ & $\begin{array}{c}-0.308^{* *} \\
(0.062)\end{array}$ \\
\hline Other & $\begin{array}{c}-12,144.603^{* *} \\
(1,882.590)\end{array}$ & $\begin{array}{c}-0.671^{* *} \\
(0.104)\end{array}$ & $\begin{array}{r}-11,736.813^{\dagger} \\
(6,113.453)\end{array}$ & $\begin{array}{r}-0.178^{\dagger} \\
(0.093)\end{array}$ \\
\hline Unemployment experience & $\begin{array}{c}-1,134.177^{* *} \\
(208.270)\end{array}$ & $\begin{array}{c}-0.063^{* *} \\
(0.012)\end{array}$ & $\begin{array}{c}-6511.192^{* *} \\
(752.720)\end{array}$ & $\begin{array}{c}-0.099^{* *} \\
(0.011)\end{array}$ \\
\hline \multicolumn{5}{|l|}{ Years of education (ref. 11-12): } \\
\hline $7-10.5$ & $\begin{array}{r}-1,664.026^{*} \\
(844.515)\end{array}$ & $\begin{array}{r}-0.092^{*} \\
(0.047)\end{array}$ & $\begin{array}{c}-8,095.792^{* *} \\
(3,033.661)\end{array}$ & $\begin{array}{c}-0.123^{* *} \\
(0.046)\end{array}$ \\
\hline $12.5+$ & $\begin{array}{c}4,217.542^{* *} \\
(919.023)\end{array}$ & $\begin{array}{l}0.233^{* *} \\
(0.051)\end{array}$ & $\begin{array}{c}5,865.468^{*} \\
(2,970.550)\end{array}$ & $\begin{array}{c}0.089^{*} \\
(0.045)\end{array}$ \\
\hline Regional unemployment rate & $\begin{array}{c}-460.623^{* *} \\
(120.904)\end{array}$ & $\begin{array}{c}-0.025^{* *} \\
(0.007)\end{array}$ & $\begin{array}{c}-3,049.386^{* *} \\
(405.021)\end{array}$ & $\begin{array}{c}-0.046^{* *} \\
(0.006)\end{array}$ \\
\hline \multicolumn{5}{|l|}{ Risk preference (ref. Medium): } \\
\hline Very low & $\begin{array}{c}1,499.648 \\
(1,211.658)\end{array}$ & $\begin{array}{c}0.083 \\
(0.067)\end{array}$ & $\begin{array}{c}3,960.432 \\
(4,224.625)\end{array}$ & $\begin{array}{c}0.060 \\
(0.064)\end{array}$ \\
\hline Low & $\begin{array}{r}2,336.474^{*} \\
(907.797)\end{array}$ & $\begin{array}{c}0.129^{*} \\
(0.050)\end{array}$ & $\begin{array}{c}6,057.598^{\dagger} \\
(3,132.140)\end{array}$ & $\begin{array}{c}0.092^{\dagger} \\
(0.047)\end{array}$ \\
\hline High & $\begin{array}{c}2,338.223^{* *} \\
(898.719)\end{array}$ & $\begin{array}{l}0.129^{* *} \\
(0.049)\end{array}$ & $\begin{array}{c}4,387.716 \\
(2,976.959)\end{array}$ & $\begin{array}{l}0.067 \\
(0.045)\end{array}$ \\
\hline Very high & $\begin{array}{c}336.067 \\
(1,254.916)\end{array}$ & $\begin{array}{c}0.019 \\
(0.069)\end{array}$ & $\begin{array}{r}-7,008.633^{\dagger} \\
(4,050.575)\end{array}$ & $\begin{array}{r}-0.106^{\dagger} \\
(0.061)\end{array}$ \\
\hline \multirow{5}{*}{$\begin{array}{l}\text { Obs. } \\
\text { IHS: } \Gamma^{a} \\
\text { Median } \\
\sigma_{\text {minimum }}{ }^{(b)} \\
\sigma_{1^{\text {st }} \text { percentile }}{ }^{(b)}\end{array}$} & 4,754 & 4,754 & 4,754 & 4,754 \\
\hline & 0.000116 & & 0.000055 & \\
\hline & 15,969 & & 63,350 & \\
\hline & 30.07 & & 25.38 & \\
\hline & 17.01 & & 14.07 & \\
\hline \multicolumn{5}{|c|}{$\begin{array}{l}\text { Notes: Estimated standard errors are corrected for multiple imputed datasets. Standard errors in parentheses; } \\
\text { Significance levels: } \dagger \mathrm{p}<0.10, * \mathrm{p}<0.05, * * \mathrm{p}<0.01 \text {. Marginal effects evaluated at the median wealth. (a) } \Gamma \text { is } \\
\text { estimated separately for each imputed dataset. Reported is the mean value. See Section A in the Appendix for more } \\
\text { information. (b) This value shows the share of savings that can be attributed to income uncertainty. The simulation } \\
\text { of } \bar{P} S^{*} \text { in equation } 6 \text { is evaluated at the minimum and the } 1^{\text {st }} \text { percentile of } \log \left(\sigma^{2}\right) \text {. } \\
\text { Source: SOEP, own calculation }\end{array}$} \\
\hline
\end{tabular}


not significant, the magnitude of the point estimate is 1,341 euro or 5.2 percent. Like the results for West Germany, this is similar to the results that are reported in Tables 11 and 12 for East Germany. The derived share of precautionary wealth in this model is 12 percent (first percentile) which is also comparable to the previous findings.

\subsection{Savings flows}

Table 11 shows the results for the savings regressions using the log of the variance $\sigma^{2}$ as uncertainty measure and log of monthly savings as dependent variable. The coefficient of income uncertainty is positive and significantly different from zero in nearly all models. The only exception is the fixed effects model for East Germany, in which the coefficient is positive but not significant. The coefficients differ between OLS, random effects and fixed effects, and the Hausman test rejects the null that the differences are not systematic at any conventional significance level. Due to larger standard errors, the confidence band of the fixed effects estimates comprises the point-estimates of both other models. The fixed effects estimates amount to 0.054 and 0.042 for West and East Germany, respectively. Since both the dependent and independent variables are in logs, the effect can be interpreted as an elasticity: Doubling $\sigma^{2}$ leads to an increase of savings by 5.4 percent in the West and by 4.2 percent in East Germany. Given a mean amount of monthly savings of 538 and 496 euro in West and East Germany this percentage increase is equivalent to about 29 and 21 euro respectively. At the bottom of Table 11 it is shown that an increase of $\log \left(\sigma^{2}\right)$ by one standard deviation increases monthly savings by roughly six percent in both West and East Germany.

The estimate of average precautionary saving is relatively sensitive to the chosen reference value $\left(\sigma_{\min }\right)$. In the fixed effects model, the share ranges between 27.6 and 16 percent or between 149 and 85 euro for West Germany. For East Germany it lies between 19.6 and 13.9 percent or between 97 and 69 euro.

With respect to the other covariates, I find that permanent income has a significant 
Table 10: Wealth regression, East Germany - marginal effects

\begin{tabular}{|c|c|c|c|c|}
\hline & \multicolumn{2}{|c|}{ Financial wealth } & \multicolumn{2}{|c|}{ Net worth } \\
\hline & Marginal effect & $\%$-change & Marginal effect & $\%$-change \\
\hline $\log \left(\sigma^{2}\right)$ & $\begin{array}{c}206.627 \\
(436.470)\end{array}$ & $\begin{array}{c}0.022 \\
(0.046)\end{array}$ & $\begin{array}{c}1,341.879 \\
(1,405.594)\end{array}$ & $\begin{array}{c}0.051 \\
(0.053)\end{array}$ \\
\hline Permanent income & $\begin{array}{l}10,598.212^{* *} \\
(1,216.054)\end{array}$ & $\begin{array}{l}1.112^{* *} \\
(0.127)\end{array}$ & $\begin{array}{l}31,431.552^{* *} \\
(3,933.071)\end{array}$ & $\begin{array}{l}1.192^{* *} \\
(0.149)\end{array}$ \\
\hline Age & $\begin{array}{c}-1,994.818 \\
(2,792.735)\end{array}$ & $\begin{array}{c}-0.209 \\
(0.293)\end{array}$ & $\begin{array}{c}3,297.789 \\
(8,416.964)\end{array}$ & $\begin{array}{c}0.125 \\
(0.319)\end{array}$ \\
\hline $\mathrm{Age}^{2} / 100$ & $\begin{array}{c}4,597.079 \\
(6,250.528)\end{array}$ & $\begin{array}{c}0.482 \\
(0.656)\end{array}$ & $\begin{array}{l}-3,622.966 \\
(18,872.979)\end{array}$ & $\begin{array}{l}-0.138 \\
(0.716)\end{array}$ \\
\hline $\mathrm{Age}^{3} / 100$ & $\begin{array}{c}-31.474 \\
(45.490)\end{array}$ & $\begin{array}{c}-0.003 \\
(0.005)\end{array}$ & $\begin{array}{c}13.699 \\
(137.585)\end{array}$ & $\begin{array}{c}0.001 \\
(0.005)\end{array}$ \\
\hline \multicolumn{5}{|l|}{ Type of household (ref. Single): } \\
\hline Single, children & $\begin{array}{c}-7,289.606^{* *} \\
(1,861.403)\end{array}$ & $\begin{array}{c}-0.765^{* *} \\
(0.195)\end{array}$ & $\begin{array}{c}-7,572.007 \\
(6,683.797)\end{array}$ & $\begin{array}{c}-0.287 \\
(0.254)\end{array}$ \\
\hline Couple, no children & $\begin{array}{l}-6982.383^{* *} \\
(1,340.049)\end{array}$ & $\begin{array}{c}-0.733^{* *} \\
(0.140)\end{array}$ & $\begin{array}{c}-13,924.989^{* *} \\
(4,093.954)\end{array}$ & $\begin{array}{c}-0.528^{* *} \\
(0.155)\end{array}$ \\
\hline Couple, children & $\begin{array}{c}-7,936.092^{* *} \\
(1,301.137)\end{array}$ & $\begin{array}{c}-0.833^{* *} \\
(0.137)\end{array}$ & $\begin{array}{c}-12,675.752^{* *} \\
(4,029.026)\end{array}$ & $\begin{array}{c}-0.481^{* *} \\
(0.153)\end{array}$ \\
\hline Other & $\begin{array}{c}-11,883.870^{* *} \\
(2,881.400)\end{array}$ & $\begin{array}{c}-1.247^{* *} \\
(0.301)\end{array}$ & $\begin{array}{r}-15,637.683^{\dagger} \\
(8,529.524)\end{array}$ & $\begin{array}{r}-0.593^{\dagger} \\
(0.323)\end{array}$ \\
\hline Experience UE & $\begin{array}{r}-342.326^{*} \\
(157.618)\end{array}$ & $\begin{array}{r}-0.036^{*} \\
(0.017)\end{array}$ & $\begin{array}{c}-891.670 \\
(554.981)\end{array}$ & $\begin{array}{c}-0.034 \\
(0.021)\end{array}$ \\
\hline \multicolumn{5}{|l|}{ Years of education (ref. 11-12): } \\
\hline $7-10.5$ & $\begin{array}{c}-30.861 \\
(1,036.094)\end{array}$ & $\begin{array}{c}-0.003 \\
(0.109)\end{array}$ & $\begin{array}{c}-2,234.525 \\
(3,224.547)\end{array}$ & $\begin{array}{c}-0.085 \\
(0.122)\end{array}$ \\
\hline $12.5+$ & $\begin{array}{c}3,743.317^{* *} \\
(849.669)\end{array}$ & $\begin{array}{l}0.393^{* *} \\
(0.089)\end{array}$ & $\begin{array}{c}1,932.097 \\
(2,697.777)\end{array}$ & $\begin{array}{c}0.073 \\
(0.102)\end{array}$ \\
\hline Regional unemployment rate & $\begin{array}{l}-66.258 \\
(149.508)\end{array}$ & $\begin{array}{c}-0.007 \\
(0.016)\end{array}$ & $\begin{array}{c}393.253 \\
(476.284)\end{array}$ & $\begin{array}{c}0.015 \\
(0.018)\end{array}$ \\
\hline \multicolumn{5}{|l|}{ Risk preference (ref. Medium): } \\
\hline Very low & $\begin{array}{c}-522.243 \\
(1,499.155)\end{array}$ & $\begin{array}{c}-0.055 \\
(0.157)\end{array}$ & $\begin{array}{c}-5,159.919 \\
(4,308.855)\end{array}$ & $\begin{array}{c}-0.196 \\
(0.163)\end{array}$ \\
\hline Low & $\begin{array}{c}-656.137 \\
(936.498)\end{array}$ & $\begin{array}{c}-0.069 \\
(0.098)\end{array}$ & $\begin{array}{c}-984.256 \\
(3,027.787)\end{array}$ & $\begin{array}{r}-0.037 \\
(0.115)\end{array}$ \\
\hline High & $\begin{array}{c}-367.998 \\
(818.200)\end{array}$ & $\begin{array}{c}-0.039 \\
(0.086)\end{array}$ & $\begin{array}{c}-1,212.161 \\
(2,642.305)\end{array}$ & $\begin{array}{c}-0.046 \\
(0.100)\end{array}$ \\
\hline Very high & $\begin{array}{c}-1,432.257 \\
(1,472.147) \\
\end{array}$ & $\begin{array}{c}-0.150 \\
(0.155) \\
\end{array}$ & $\begin{array}{c}3,677.980 \\
(4,331.052) \\
\end{array}$ & $\begin{array}{c}0.139 \\
(0.164) \\
\end{array}$ \\
\hline \multirow{5}{*}{$\begin{array}{l}\text { Obs. } \\
\text { IHS: } \Gamma^{a} \\
\text { Median } \\
\sigma_{\text {minimum }}^{(b)} \\
\sigma_{1^{\text {st }} \text { percentile }}^{(b)} \\
\end{array}$} & 1,253 & 1,253 & 1,253 & 1,253 \\
\hline & 0.000193 & & 0.000144 & \\
\hline & 8,000 & & 25,456 & \\
\hline & 11.83 & & 15.67 & \\
\hline & 9.24 & & 12.24 & \\
\hline \multicolumn{5}{|c|}{$\begin{array}{l}\text { Notes: Estimated standard errors are corrected for multiple imputed datasets. Standard errors in parentheses } \\
\text { Significance levels: } \dagger \mathrm{p}<0.10, * \mathrm{p}<0.05, * * \mathrm{p}<0.01 \text {. Marginal effects evaluated at the median wealth. (a) } \Gamma \text { is } \\
\text { estimated separately for each imputed dataset. Reported is the mean value. See Section A in the Appendix for mor } \\
\text { information. (b) This value shows the share of savings that can be attributed to income uncertainty. The simulation } \\
\text { of } \bar{P} S^{*} \text { in equation } 6 \text { is evaluated at the minimum and the } 1^{\text {st }} \text { percentile of } \log \left(\sigma^{2}\right) \text {. } \\
\text { Source: SOEP, own calculation }\end{array}$} \\
\hline
\end{tabular}


Table 11: Savings flows regression by region (log savings, different models)




and positive effect on saving in the OLS and random effects model. However, due to its construction, I cannot estimate a coefficient for permanent income in the fixed effects model since it is collinear. Interestingly, the dummies controlling for the type of household switch sign when we control for fixed effects. Note that the reference category is a single household without children. At first sight, this is surprising because the negative sign in the other two models could be explained by controlling for permanent income. Since permanent household income is not weighted, it captures part of the effect of household size. It is different, however, in the fixed effects model: these household characteristics capture part of the effect of household income in this model specification. When I include the current net household income in this regression (estimation not shown), the significant coefficients disappear with the exception of a higher saving rate of couple households without children. Economies of household size are a reasonable explanation. ${ }^{25}$

How robust are these findings to the exclusion of observations with zero monthly savings? To answer this question, a random effects tobit model is estimated using all observations. Savings amounts enter the model in levels. ${ }^{26}$ Table 12 shows the estimated marginal effects. Following McDonald and Moffitt (1980), the marginal effects are decomposed: The first column for each set of estimates presents the unconditional marginal effect, the second column the conditional marginal effect, and the third column the probability of being uncensored.

A straightforward way to compare the results between models is to look at the estimated conditional share of precautionary saving. The tobit model results in very similar amounts of precautionary saving as the fixed effects regression of log savings flows. Evaluated at the first percentile, its share is about 14 percent in the tobit model compared to 16

25 The finding that singles save more than other households when permanent income is controlled for is also found in other studies, e.g., in the papers by Fuchs-Schündeln and Schündeln (2005), Bartzsch (2008), and Fossen and Rostam-Afschar (2009).

26 A common practice is to add a constant, often unity, to savings and to apply the log-transformation. However, the choice of the added constant is arbitrary and results may be sensitive to the chosen constant. 
Table 12: Savings flows regression including all observations, marginal effects of random effects tobit models by region (estimation in levels)

\begin{tabular}{|c|c|c|c|c|c|c|}
\hline & \multicolumn{3}{|c|}{ West Germany } & \multicolumn{3}{|c|}{ East Germany } \\
\hline & Uncond. & Cond. & Prob. & Uncond. & Cond. & Prob. \\
\hline $\log \left(\sigma^{2}\right)$ & $\begin{array}{l}37.152^{* *} \\
(4.488)\end{array}$ & $\begin{array}{l}27.624^{* *} \\
(3.343)\end{array}$ & $\begin{array}{c}0.032^{* *} \\
(0.004)\end{array}$ & $\begin{array}{l}30.703^{* *} \\
(6.761)\end{array}$ & $\begin{array}{l}23.158^{* *} \\
(5.109)\end{array}$ & $\begin{array}{c}0.029^{* *} \\
(0.006)\end{array}$ \\
\hline Log permanent income & $\begin{array}{l}367.173^{* *} \\
(16.748)\end{array}$ & $\begin{array}{l}273.007^{* *} \\
(12.730)\end{array}$ & $\begin{array}{c}0.313^{* *} \\
(0.014)\end{array}$ & $\begin{array}{l}279.253^{* *} \\
(27.220)\end{array}$ & $\begin{array}{c}210.630^{* *} \\
(20.944)\end{array}$ & $\begin{array}{c}0.268^{* *} \\
(0.025)\end{array}$ \\
\hline \multicolumn{7}{|c|}{ Type of household (ref. Single): } \\
\hline Single, children & $\begin{array}{c}-37.222 \\
(27.581)\end{array}$ & $\begin{array}{c}-27.676 \\
(20.510)\end{array}$ & $\begin{array}{c}-0.032 \\
(0.024)\end{array}$ & $\begin{array}{r}-73.531^{\dagger} \\
(40.685)\end{array}$ & $\begin{array}{r}-55.462^{\dagger} \\
(30.706)\end{array}$ & $\begin{array}{r}-0.071^{\dagger} \\
(0.039)\end{array}$ \\
\hline Couple, no children & $\begin{array}{l}48.810^{* *} \\
(13.318)\end{array}$ & $\begin{array}{l}36.292^{* *} \\
(9.901)\end{array}$ & $\begin{array}{c}0.042^{* *} \\
(0.011)\end{array}$ & $\begin{array}{l}74.416^{* *} \\
(23.616)\end{array}$ & $\begin{array}{c}56.129^{* *} \\
(17.799)\end{array}$ & $\begin{array}{c}0.071^{* *} \\
(0.022)\end{array}$ \\
\hline Couple, children & $\begin{array}{c}-52.578^{* *} \\
(13.431)\end{array}$ & $\begin{array}{c}-39.094^{* *} \\
\quad(9.996)\end{array}$ & $\begin{array}{c}-0.045^{* *} \\
(0.012)\end{array}$ & $\begin{array}{c}-16.512 \\
(24.265)\end{array}$ & $\begin{array}{c}-12.455 \\
(18.310)\end{array}$ & $\begin{array}{c}-0.016 \\
(0.023)\end{array}$ \\
\hline Other & $\begin{array}{c}-67.769^{* *} \\
(17.921)\end{array}$ & $\begin{array}{c}-50.389^{* *} \\
(13.336)\end{array}$ & $\begin{array}{c}-0.058^{* *} \\
(0.015)\end{array}$ & $\begin{array}{c}-28.114 \\
(37.452)\end{array}$ & $\begin{array}{c}-21.206 \\
(28.259)\end{array}$ & $\begin{array}{c}-0.027 \\
(0.036)\end{array}$ \\
\hline Unemployment experience & $\begin{array}{c}-12.882^{* *} \\
(3.394)\end{array}$ & $\begin{array}{c}-9.578^{* *} \\
(2.523)\end{array}$ & $\begin{array}{c}-0.011^{* *} \\
(0.003)\end{array}$ & $\begin{array}{r}-11.667^{*} \\
(5.136)\end{array}$ & $\begin{array}{c}-8.800^{*} \\
(3.873)\end{array}$ & $\begin{array}{c}-0.011^{*} \\
(0.005)\end{array}$ \\
\hline \multicolumn{7}{|c|}{ Years of education (ref. 11-12): } \\
\hline $7-10.5$ & $\begin{array}{l}-2.264 \\
(13.848)\end{array}$ & $\begin{array}{l}-1.683 \\
(10.297)\end{array}$ & $\begin{array}{c}-0.002 \\
(0.012)\end{array}$ & $\begin{array}{r}-64.717^{*} \\
(27.597)\end{array}$ & $\begin{array}{r}-48.813^{*} \\
(20.823)\end{array}$ & $\begin{array}{c}-0.062^{*} \\
(0.026)\end{array}$ \\
\hline $12.5+$ & $\begin{array}{c}92.616^{* *} \\
(14.238)\end{array}$ & $\begin{array}{c}68.864^{* *} \\
(10.628)\end{array}$ & $\begin{array}{c}0.079^{* *} \\
(0.012)\end{array}$ & $\begin{array}{c}93.378^{* *} \\
(21.245)\end{array}$ & $\begin{array}{c}70.432^{* *} \\
(16.129)\end{array}$ & $\begin{array}{c}0.090^{* *} \\
(0.020)\end{array}$ \\
\hline Positive savings & & & 0.67 & & & 0.66 \\
\hline Conditional mean & & 538 & & & 497 & \\
\hline Unconditional mean & 358 & & & 326 & & \\
\hline$\sigma_{\text {minimum }}{ }^{(a)}$ & 69.28 & 31.93 & & 41.05 & 18.03 & \\
\hline$\sigma_{p 1}^{(a)}$ & 30.59 & 13.59 & & 31.28 & 14.08 & \\
\hline No. of groups & 3,852 & 3,852 & 3,852 & 1,046 & 1,046 & 1,046 \\
\hline Obs. & 18,870 & 18,870 & 18,870 & 4,928 & 4,928 & 4,928 \\
\hline \multicolumn{7}{|c|}{$\begin{array}{l}\text { Notes: (a) This value shows the share of savings that can be attributed to income uncertainty. The simulation of } \\
P S^{*} \text { in equation } 6 \text { is evaluated at the minimum and the } 1^{\text {st }} \text { percentile of } \log \left(\sigma^{2}\right) \text {. Standard errors in parentheses; } \\
\text { Significance levels: } \dagger \mathrm{p}<0.10, * \mathrm{p}<0.05, * * \mathrm{p}<0.01 \\
\text { Source: SOEP, own calculation }\end{array}$} \\
\hline
\end{tabular}


(West Germany) and 14 (East Germany) percent in the fixed effects model. In addition, the table shows the share with respect to the unconditional mean of the latent variable $s^{*}$. The share is considerably higher than for the conditional mean and sensitive to the evaluation at the minimum compared to the first percentile - at least for West Germany. The shares evaluated at the first percentile are about 30 percent in both samples.

A doubling of income uncertainty would increase the conditional mean value by about 28 euro or 5.2 percent in West Germany. And for East Germany, it would increase by 23 euro or 4.6 percent. Both estimates are close to the fixed effects coefficients. Of course, the effect of doubling $\sigma^{2}$ on the unconditional mean is larger. It amounts to 37 euro or ten percent and to 31 euro or 9.5 percent in West and East Germany, respectively. The change can also be calculated in terms of the savings rate. For example, using permanent income and the average unconditional amount of monthly savings the savings rate is 9.9 percent in West Germany. An increase of 37 euro increases the unconditional savings rate by about ten percent.

This model also shows that the uncertainty measure has a positive and significant impact on the probability to save. In both regions the effect amounts to roughly three percentage points. Given the share of 66 percent observations with positive monthly savings, this is equivalent to an increase of about 4.5 percent. 


\section{Conclusion}

The theory of precautionary savings predicts that individuals accumulate precautionary wealth to insure themselves against expected (uninsured) future income shocks. Empirical evidence on precautionary savings might be important for government policies that have an impact on income uncertainty. The concept has a strong theoretical foundation but the empirical results show an exceptionally rich diversity ranging from zero precautionary savings to more than half of all wealth. The few studies for Germany are no exception, and results vary considerably.

A potential reason for this diversity are the methodological problems associated with the precautionary savings model. I suggest that the prevalence of ex-post measures of economic risks is likely to neglect important aspects of the precautionary motive. As an alternative I propose an ex-ante risk measure. The innovation of this study is the way net household income variance is simulated and used in a model of precautionary savings. Starting from the fact that unemployment is one of the most important economic risks and has a strong linkage with health, the simulation model is built around a joint estimation of health and unemployment risks. In addition to employment risks, wages in the model depend on previous unemployment and health. The inherent path dependence is exploited by simulating three future periods. To generate net household incomes, a detailed tax benefit microsimulation model is applied. This will allow to simulate changes in the tax-benefit system and their likely impact on precautionary savings in future analyses.

All models are estimated separately for East and West Germany. The results underline that the regional differentiation of labour markets indeed matters. The estimates show that unemployment risks are not only higher in East Germany but also react more strongly to deteriorated health. On the other hand, I do not find any significantly negative effect of previous unemployment on wages in East Germany whereas a large 
effect of 7.3 percent can be found in West Germany. I do not find any significant direct effect of health on wages.

I find evidence for precautionary savings in response to the uncertainty measures. This result holds for various specifications of a savings flows regression and the buffer-stock wealth model. First, an ad-hoc savings regression is specified. The data on savings flows allow to apply panel estimators and are used to compare the magnitude of the effects of the second model, a standard buffer-stock wealth model. Income uncertainty has a significant positive effect on savings flows in both East and West Germany. The relative effect is similar between regions although absolute savings are higher in West Germany. If income uncertainty doubles, monthly savings increase by about five percent. A conservative counterfactual simulation shows that about 16 percent of savings flows can be attributed to the precautionary motive in West Germany. The share is slightly lower in the East and amounts to 14 percent. These results were estimated using log-savings as dependent variable. However, the estimation is robust to the inclusion of zero-savings observations and estimating a random effects tobit.

The buffer-stock wealth model is estimated for two different wealth aggregates, financial wealth and net worth. In contrast to many other studies the results are robust to the chosen wealth measure - at least for West Germany. Income uncertainty is again significantly positive. An increase by 100 percent leads to a five percent increase in precautionary wealth. Simulations suggest that about 17 percent of financial assets and 14 percent of net worth has been accumulated due to the precautionary motive. The lower value for net worth suggests that a part of housing equity serves as precautionary savings.

The results for East Germany are somewhat less stable and require further investigation. The coefficient of income uncertainty is not significant and the point estimate is higher for net worth, which is counterintuitive. However, a closer look at the results for net worth shows that the effect - although insignificant - are similar to those estimated for 
the West German subsample.

In general, and in contrast to a number of empirical studies on precautionary savings, my results are very robust and stable. Thus, they can be considered strong evidence for a share of precautionary wealth of about 14 to 17 percent. These estimates are conservative in the sense that they are not evaluated at the minimum risk but at the first percentile in order to avoid extreme outliers. In sum, I can show that a neither non-negligible nor extremely large part of savings flows and stocks results from the precautionary motive, and that the proposed measure of income uncertainty is a promising approach to the modelling of income risks. 


\section{Appendix}

\section{A. Wealth transformation}

The inverse hyperbolic sine (IHS) function $\sinh ^{-1}$ offers a solution to the problem of zero or negative values of the dependent variable. Burbidge et al. (1988) suggest a general version of the inverse hyperbolic sine, defined as:

$$
f^{I H S}(w, \Gamma)=\frac{\ln \left[\Gamma w+\left(\Gamma^{2} w^{2}+1\right)^{\frac{1}{2}}\right]}{\Gamma^{-1}}=\frac{\sinh ^{-1}(\Gamma w)}{\Gamma}
$$

where $w$ is the observed wealth variable and $\Gamma$ is a scaling parameter that allows the distribution to be leptokurtic. ${ }^{27}$

The function is linear around the origin and symmetric. For large $w$, the function is approximately a parallel shift of the logarithm: $\ln \left[\Gamma w+\left(\Gamma^{2} w^{2}+1\right)^{\frac{1}{2}}\right] \approx \ln 2 \Gamma+\ln w$.

Pence (2006) shows how to calculate the marginal effects with an IHS-transformed dependent variable. Assume the following model:

$$
y=f^{I H S}(\Gamma, w)=f(\Gamma)=x \beta+\varepsilon
$$

The marginal effect of a change in $x$ is then given by $0.5\left(e^{\Gamma y}+e^{-\Gamma y}\right) \beta$. It is also possible to use the approximation $\beta \Gamma$ for large $w$; it approximates the percentage change in $w$ for a unit change in $x$. Both types of marginal effects are reported in Tables 9 and 10. The marginal effects are calculated at the median wealth of the regression sample.

Burbidge et al. (1988) derive a likelihood function to determine the optimal $\Gamma$ in the case of an OLS estimator. Assuming normally distributed errors, the concentrated log-likelihood for $\Gamma$ in (19) is

$$
l^{c}(\Gamma)=(\text { constant })-\frac{n}{2} \ln f(\Gamma)^{\prime} M f(\Gamma)-\frac{1}{2} \sum \ln \left(1+\Gamma^{2} w^{2}\right)
$$

where $M=I-x\left(x^{\prime} x\right)^{-1} x^{\prime}$. To estimate the optimal $\Gamma$ a grid search over $\Gamma \geqq 0$ is

27 Ramirez et al. (1994) show that the normal distribution is only a special case as $\Gamma$ approaches zero. 
performed to maximize (20). ${ }^{28}$ The grid search was performed for each of the imputed datasets.

\section{B. Combing results across multiple imputed datasets: "Rubin's rule"}

As described in Frick et al. (2007), missing wealth information in the SOEP data $(2002,2007)$ were imputed using a multiple imputation procedure. The idea behind this approach is to generate a number of different complete datasets by imputing missing values and to conduct separate statistical analyses on each of the imputed datasets. The different results are then combined according to "Rubin's rule" (Rubin, 1987). This procedure takes into account the variation between results obtained in each of the imputed datasets and allows to account for the uncertainty involved with imputing missing values.

Suppose we are interested in a scalar quantity $Q$, for example the coefficients or marginal effects of the buffer-stock model. Let $\hat{Q}_{j}$ and $\hat{V}_{j}$ be parameter and variance estimates from imputed dataset $j$ with $j=1, \ldots, m$. The overall point estimate $\hat{Q}$ is the mean of the $m$ estimates: ${ }^{29}$

$$
\hat{Q}=\frac{1}{m} \sum_{j=1}^{m} \hat{Q}_{j}
$$

A valid standard error of the estimated $\hat{Q}$ is obtained by combining within and between variation of the imputations:

$$
\begin{array}{rlrl}
\hat{V}^{w} & =\frac{1}{m} \sum_{j=1}^{m} \hat{V}_{j} & \text { (wihtin variance) } \\
\hat{V}^{b} & =\frac{1}{m-1} \sum_{j=1}^{m}\left(\hat{V}_{j}-\hat{V}^{w}\right)^{2} & \text { (between variance) } \\
\hat{V} & =\hat{V}^{w}+1+\frac{1}{m} \hat{V}^{b} & & \text { (total variance) }
\end{array}
$$

28 Pence (2006) derives a similar likelihood function for a quantile regression.

29 The exposition is based on Carlin et al. (2003). 
Rubin (1987) shows that approximately,

$$
\hat{V}^{-\frac{1}{2}}(Q-\hat{Q}) \sim t_{d f}
$$

where the degrees of freedom $d f$ are given by

$$
d f=(m-1)+\left(1+\frac{\hat{V}^{w}}{\left(1+\frac{1}{m}\right) \hat{V}^{b}}\right)^{2}
$$

A $100(1-\alpha) \%$ confidence interval for $\hat{Q}$ is

$$
\hat{Q} \pm t_{d f, 1-\frac{\alpha}{2}} \sqrt{\hat{V}}
$$




\section{Tables}

Table 13: Overview on selected empirical papers on precautionary savings

\begin{tabular}{|c|c|c|c|c|c|}
\hline Paper & Data & Sample & Dependent variable & Risk measure & Results \\
\hline Skinner (1988) & $\mathrm{CE}$ & $\begin{array}{l}\text { 1972/1973, Couple households } \\
\text { with household heads aged be- } \\
\text { tween } 20 \text { and } 50 \text {, savings rates } \\
\text { lower than } 50 \% \text {, income be- } \\
\text { tween } 2,000 \text { and } 35,000 \text { dollars }\end{array}$ & $\begin{array}{l}\text { Difference between } \\
\text { net income and con- } \\
\text { sumption (with and } \\
\text { without consumption } \\
\text { durables) }\end{array}$ & Occupational status & $\begin{array}{l}\text { Derives a share of more than } \\
50 \% \text { of precautionary savings in } \\
\text { a theoretical model of consump- } \\
\text { tion. The empirical estimates } \\
\text { do not show evidence for precau- } \\
\text { tionary savings. Individuals in } \\
\text { supposedly riskier occupations } \\
\text { save less. }\end{array}$ \\
\hline Guiso et al. (1992) & SHIW & $\begin{array}{l}\text { 1989, Household head depen- } \\
\text { dently employed and younger } \\
\text { than } 65 \text {, households with nega- } \\
\text { tive net worth were excluded }\end{array}$ & Net worth & $\begin{array}{l}\text { Self-reported measure } \\
\text { of uncertainty of fu- } \\
\text { ture earnings and } \\
\text { inflation (one year } \\
\text { ahead) }\end{array}$ & $\begin{array}{l}\text { Precautionary savings account } \\
\text { for } 2 \% \text { of total net worth }\end{array}$ \\
\hline Dynan (1993) & $\mathrm{CE}$ & 1985 & $\begin{array}{l}\text { Consumption growth } \\
\text { (Non-durables) }\end{array}$ & $\begin{array}{l}\text { Squared consumption } \\
\text { growth }\end{array}$ & $\begin{array}{l}\text { Estimates the coefficient of rela- } \\
\text { tive prudence as defined in Kim- } \\
\text { ball (1990). The coefficient is } \\
\text { not significant, i.e. no indica- } \\
\text { tion of precautionary savings. }\end{array}$ \\
\hline Dardanoni (1991) & FES & $\begin{array}{l}1984 \text { Households whose head is } \\
\text { single earner and dependently } \\
\text { employed }\end{array}$ & Total expenditures & $\begin{array}{l}\text { Occupation specific } \\
\text { earnings variance }\end{array}$ & $\begin{array}{l}\text { Estimates an equation for opti- } \\
\text { mal consumption derived from } \\
\text { an intertemporal maximization } \\
\text { problem. About } 60 \% \text { of all sav- } \\
\text { ings in the sample arise from } \\
\text { precautionary motives }\end{array}$ \\
\hline
\end{tabular}

continued on next page... 
Table 13 - continued from previous page

\begin{tabular}{|c|c|c|c|c|c|}
\hline Paper & Data & Sample & Dependent variable & Risk measure & Results \\
\hline Carroll (1994) & $\begin{array}{l}\mathrm{CE} / \\
\mathrm{PSID}\end{array}$ & $\begin{array}{l}1960 / 1961 \text { Households whose } \\
\text { head is between } 25 \text { and } 65 \text { years } \\
\text { of age }\end{array}$ & Current consumption & $\begin{array}{l}\text { Imouted variance } \\
\text { measures, estimated } \\
\text { on future waves of } \\
\text { PSID }\end{array}$ & $\begin{array}{l}\text { A one standard deviation in- } \\
\text { crease in the "equivalent precau- } \\
\text { tionary premium" (EPP) (Kim- } \\
\text { ball, 1990) increases savings } \\
\text { rates by more than three per- } \\
\text { cent. }\end{array}$ \\
\hline $\begin{array}{l}\text { Hubbard et al. } \\
(1995)\end{array}$ & PSID & 1984 Full sample & Net worth & $\begin{array}{l}\text { life-span uncertainty, } \\
\text { earnings uncertainty } \\
\text { (permanent variance), } \\
\text { and uncertainty } \\
\text { about out-of-pocket } \\
\text { medical expenditures }\end{array}$ & $\begin{array}{l}\text { Estimate a multiperiod dy- } \\
\text { namic programming model and } \\
\text { find that differences in wealth } \\
\text { of different groups can be ex- } \\
\text { plained by the interaction of un- } \\
\text { certainty and means tested so- } \\
\text { cial insurance programs. }\end{array}$ \\
\hline \multicolumn{6}{|l|}{$\begin{array}{l}\text { Browning and } \\
\text { Lusardi (1996) }\end{array}$} \\
\hline $\begin{array}{l}\text { Carroll and } \\
\text { Samwick (1997) }\end{array}$ & PSID & $\begin{array}{l}1984 \text { Households aged } 50 \text { and } \\
\text { younger }\end{array}$ & $\begin{array}{l}\text { Wealth: (1) liquid } \\
\text { financial wealth, } \\
(2) \quad \text { Non-housing, } \\
\text { non-business wealth, } \\
\text { (3) total net worth }\end{array}$ & $\begin{array}{l}\text { Permanent and tran- } \\
\text { sitory variance of to- } \\
\text { tal gross household } \\
\text { income based, esti- } \\
\text { mated on PSID waves } \\
\text { 1981-1987 }\end{array}$ & $\begin{array}{l}\text { Significant effects of transitory } \\
\text { and permanent income variance; } \\
\text { No significant effects if self- } \\
\text { employed and farmers are ex- } \\
\text { cluded }\end{array}$ \\
\hline Kazarosian (1997) & NLS & $\begin{array}{l}1965-1980 \text { Male household } \\
\text { heads between } 45 \text { and } 59 \text { in } \\
1966\end{array}$ & $\begin{array}{l}\text { Total net worth in- } \\
\text { cluding business as- } \\
\text { sets }\end{array}$ & Decomposed variance & $\begin{array}{l}\text { A doubling of uncertainty in- } \\
\text { creases savings by } 29 \% \text {. }\end{array}$ \\
\hline Lusardi (1997) & SHIW & $\begin{array}{l}\text { Same sample as in Guiso et al. } \\
(1992)\end{array}$ & Net worth & $\begin{array}{l}\text { Self-reported measure } \\
\text { of uncertainty of fu- } \\
\text { ture earnings and } \\
\text { inflation (one year } \\
\text { ahead) }\end{array}$ & $\begin{array}{l}\text { OLS estimates replicate the re- } \\
\text { sults in Guiso et al. (1992); but } \\
\text { IV methods lead to much higher } \\
\text { shares of precautionary savings } \\
\text { of about } 20 \% \text { to } 24 \% \text { of total } \\
\text { net worth. }\end{array}$ \\
\hline
\end{tabular}

continued on next page... 
Table 13 - continued from previous page

\begin{tabular}{|c|c|c|c|c|c|}
\hline Paper & Data & Sample & Dependent variable & Risk measure & Results \\
\hline $\begin{array}{l}\text { Carroll and } \\
\text { Samwick (1998) }\end{array}$ & PSID & $\begin{array}{l}1984 \text { Households whose head is } \\
\text { younger than } 50\end{array}$ & $\begin{array}{l}\text { same measures as in } \\
\text { Carroll and Samwick } \\
(1997)\end{array}$ & $\begin{array}{l}\text { Log of a noramlised } \\
\text { version of EPP }\end{array}$ & $\begin{array}{l}\text { Precautionary savings account } \\
\text { for about one third of liquid } \\
\text { wealth, half of non-housing, } \\
\text { non-business wealth, and } 45 \% \\
\text { of total net worth. No signifi- } \\
\text { cant effects if self-employed and } \\
\text { farmers are excluded. }\end{array}$ \\
\hline Lusardi (1998) & HRS & $\begin{array}{l}\text { Households with dependently } \\
\text { employed household head, aged } \\
\text { between } 51 \text { and } 61 \text { (wave(s) not } \\
\text { indicated) }\end{array}$ & $\begin{array}{l}\text { Financial net wealth } \\
\text { and total net worth } \\
\text { (including business } \\
\text { and home equity) }\end{array}$ & $\begin{array}{l}\text { Self-assessed unem- } \\
\text { ployment risk }(p) \text { and } \\
\text { current income }(Y) \text { : } \\
\text { variance measure } \\
\text { equals } p(1-p) Y^{2} \text {. } \\
\text { i.e. unemployment in- } \\
\text { surance replacement } \\
\text { rate is zero }\end{array}$ & $\begin{array}{l}\text { Precautionary wealth accounts } \\
\text { for } 1 \text { to } 3.5 \% \text { of net worth and } \\
2 \text { to } 4.5 \% \text { of financial wealth. }\end{array}$ \\
\hline $\begin{array}{l}\text { Engen and Gruber } \\
(2001)\end{array}$ & SIPP & $\begin{array}{l}\text { 1984-1990 Household head be- } \\
\text { tween } 25 \text { and } 64 \text {; must have } \\
\text { wage earnings from a non-self } \\
\text { employment job }\end{array}$ & Gross financial assets & $\begin{array}{l}\text { Unemployment in- } \\
\text { surance replacement } \\
\text { rate; unemployment } \\
\text { risk }\end{array}$ & $\begin{array}{l}\text { Reducing the generosity of un- } \\
\text { employment benefits by } 50 \% \\
\text { would raise financial assets by } \\
14 \%\end{array}$ \\
\hline Arrondel (2002) & INSEE & $\begin{array}{l}1997 \text { Full sample of house- } \\
\text { holds whose income is greater } \\
\text { than their current consumption } \\
\text { ("non-constrained") }\end{array}$ & $\begin{array}{l}\text { Financial wealth, to- } \\
\text { tal net worth }\end{array}$ & $\begin{array}{l}\text { Self-assessed earnings } \\
\text { variance over the next } \\
5 \text { years }\end{array}$ & $\begin{array}{l}\text { Precautionary savings account } \\
\text { for } 4.9 \text { to } 5.6 \% \text { of financial } \\
\text { wealth and for } 3.9 \text { to } 4.6 \% \text { of } \\
\text { net worth }\end{array}$ \\
\hline Carroll et al. (2003) & $\begin{array}{l}\mathrm{CPS} / \\
\mathrm{SCF}\end{array}$ & $\begin{array}{l}1983,1989,1992 \quad \text { Household } \\
\text { heads between } 20 \text { and } 65 \text { years } \\
\text { of age }\end{array}$ & Net worth & $\begin{array}{l}\text { Probability of job loss } \\
\text { next year }\end{array}$ & $\begin{array}{l}\text { Significant effects for house- } \\
\text { holds in higher permanent in- } \\
\text { come groups. The effects van- } \\
\text { ish if housing wealth is excluded } \\
\text { from the wealth aggregate. }\end{array}$ \\
\hline
\end{tabular}

continued on next page... 
Table $\mathbf{1 3}$ - continued from previous page

\begin{tabular}{|c|c|c|c|c|c|}
\hline Paper & Data & Sample & Dependent variable & Risk measure & Results \\
\hline Murata (2003) & JPSC & $\begin{array}{l}\text { 1994, } 1996 \text { Couple households } \\
\text { whose reference person is aged } \\
\text { between } 27 \text { and } 37 \text {, in which } \\
\text { the wive does not work full-time. } \\
\text { Self-employed and business own- } \\
\text { ers are excluded. }\end{array}$ & $\begin{array}{l}\text { Net worth, financial } \\
\text { assets }\end{array}$ & $\begin{array}{l}\text { Japan's economic out- } \\
\text { look (self-assessed), } \\
\text { self-assessed uncer- } \\
\text { tainty with respect } \\
\text { to Japan's public } \\
\text { pension system }\end{array}$ & $\begin{array}{l}\text { Uncertainty about public pen- } \\
\text { sions leads nuclear families but } \\
\text { not extended families to in- } \\
\text { crease precautionary wealth. } \\
\text { Using economic prospects as } \\
\text { proxy for uncertainty gives no } \\
\text { significant results. }\end{array}$ \\
\hline $\begin{array}{l}\text { Kennickell and } \\
\text { Lusardi (2004) }\end{array}$ & $\mathrm{SCF}$ & $\begin{array}{l}\text { 1995, } 1998 \text { Three samples of } \\
\text { households whose head is (1) de- } \\
\text { pendently employed and aged } \\
\text { between } 21 \text { and } 60,(2) \text { not self- } \\
\text { employed and older than } 62 \text {, } \\
\text { and (3) business owner }\end{array}$ & $\begin{array}{l}\text { Desired amount of } \\
\text { precautionary wealth }\end{array}$ & $\begin{array}{l}\text { Regional level of } \\
\text { unemployment, ex- } \\
\text { pectations about } \\
\text { income development } \\
\text { (also: health and } \\
\text { longevity risk) }\end{array}$ & $\begin{array}{l}\text { The descriptive analysis shows } \\
\text { a share of precautionary wealth } \\
\text { of } 8 \% \text { of net worth and } 20 \% \text { of } \\
\text { liquid wealth. Significance and } \\
\text { importance of risk measures dif- } \\
\text { fer by estimation samples. }\end{array}$ \\
\hline Essig (2005) & SAVE & 2003 Full sample & $\begin{array}{l}\text { Saving rate, financial } \\
\text { wealth, net worth }\end{array}$ & $\begin{array}{l}\text { Several subjective } \\
\text { measures, variance } \\
\text { of net income as in } \\
\text { Lusardi (1998) but } \\
\text { uses an individual } \\
\text { unemployment re- } \\
\text { placement rate for } \\
\text { the calculation }\end{array}$ & $\begin{array}{l}\text { The more volatile the past in- } \\
\text { come development the lower the } \\
\text { saving rate. Variance of net in- } \\
\text { come is insignificant. }\end{array}$ \\
\hline $\begin{array}{l}\text { Fuchs-Schündeln } \\
\text { and Schündeln } \\
(2005)\end{array}$ & SOEP & $\begin{array}{l}\text { 1998-2000 Main income earner } \\
\text { of the household is younger } \\
\text { than } 56 \text { and labour force par- } \\
\text { ticipant, not self-employed; sub- } \\
\text { samples that focus on migrants } \\
\text { are dropped from the analysis }\end{array}$ & $\begin{array}{l}\text { Imputed gross wealth } \\
\text { measure using infor- } \\
\text { mation on interest } \\
\text { and dividend income } \\
\text { and housing wealth }\end{array}$ & Occupational status & $\begin{array}{l}\text { Precautionary savings: } 20 \% \text { in } \\
\text { East and } 12 \% \text { in West Germany; } \\
60 \% \text { in East and no precaution- } \\
\text { ary savings if zero-wealth obser- } \\
\text { vations are included (tobit) }\end{array}$ \\
\hline
\end{tabular}

continued on next page... 
Table $\mathbf{1 3}$ - continued from previous page

\begin{tabular}{|c|c|c|c|c|c|}
\hline Paper & Data & Sample & Dependent variable & Risk measure & Results \\
\hline $\begin{array}{l}\text { Bartzsch } \quad(2006, \\
2008)\end{array}$ & SOEP & $\begin{array}{l}2002 \text { Households whose head } \\
\text { is younger than } 55, \text { not self- } \\
\text { employed, not in education or } \\
\text { military service, not retired, } \\
\text { German citizen, has always par- } \\
\text { ticipated in SOEP between } 1998 \\
\text { and } 2004\end{array}$ & $\begin{array}{l}\text { Wealth: (1) net fi- } \\
\text { nancial wealth }(2) \text { net } \\
\text { financial wealth and } \\
\text { housing wealth }\end{array}$ & $\begin{array}{l}\text { Different variance } \\
\text { measures based on } \\
\text { net total household } \\
\text { income 1998-2002 }\end{array}$ & $\begin{array}{l}\text { Positive and significant effects } \\
\text { with respect to financial wealth, } \\
\text { estimates of the share of precau- } \\
\text { tionary savings range between } \\
14.6 \% \text { and } 26.7 \% \text {. Negative or } \\
\text { insignificant effects if housing } \\
\text { wealth is included. }\end{array}$ \\
\hline Benito (2006) & BHPS & $\begin{array}{l}1992-1998 \text { Households whose } \\
\text { head is aged between } 21 \text { and } \\
65\end{array}$ & $\begin{array}{l}\text { Weekly expenditures } \\
\text { on food and groceries }\end{array}$ & $\begin{array}{l}\text { Predicted probability } \\
\text { of unemployment; } \\
\text { self-assessd job } \\
\text { insecurity }\end{array}$ & $\begin{array}{l}\text { A one standard deviation in- } \\
\text { crease in predicted unemploy- } \\
\text { ment probability decreases con- } \\
\text { sumption by } 2.7 \% \text {; No signifi- } \\
\text { cant effect of self-assessed job } \\
\text { insecurity. }\end{array}$ \\
\hline $\begin{array}{l}\text { Fossen and Rostam- } \\
\text { Afschar (2009) }\end{array}$ & SOEP & $\begin{array}{l}2002,2007 \text { Households with } \\
\text { household heads between } 18 \\
\text { and } 55 \text { who are employed }\end{array}$ & Net worth & $\begin{array}{l}\text { Different income vari- } \\
\text { ance measures }\end{array}$ & $\begin{array}{l}\text { Positive shares of precaution- } \\
\text { ary savings disappear when ac- } \\
\text { counting for entrpreneurs. }\end{array}$ \\
\hline $\begin{array}{l}\text { Beznoska and } \\
\text { Ochmann (2010) }\end{array}$ & $\begin{array}{l}\text { SOEP/ } \\
\text { LWR }\end{array}$ & $\begin{array}{l}2002-2007 \text { Households exclud- } \\
\text { ing the self-employed }\end{array}$ & Savings rates & $\begin{array}{l}\text { Permanent and tran- } \\
\text { sitory net income vari- } \\
\text { ance }\end{array}$ & $\begin{array}{l}\text { Doubling of average transitory } \\
\text { income uncertainty increases } \\
\text { savings by } 4.4 \% \text { or about } 43 \\
\text { euro for an average household. } \\
\text { Effects vary with type of house- } \\
\text { hold. }\end{array}$ \\
\hline Hurst et al. (2010) & PSID & $\begin{array}{l}\text { 1984, } 1994 \text { Households whose } \\
\text { head is aged between } 26 \text { and } 50 \text {, } \\
\text { has positve net worth }\end{array}$ & Net worth & $\begin{array}{l}\text { Decomposed income } \\
\text { variance }\end{array}$ & $\begin{array}{l}\text { The share of precautionary sav- } \\
\text { ings in total wealth drops from } \\
50 \% \text { to less than } 10 \% \text { when ac- } \\
\text { counting for differences between } \\
\text { self-employed and other groups. }\end{array}$ \\
\hline
\end{tabular}

continued on next page... 
Table $\mathbf{1 3}$ - continued from previous page

\begin{tabular}{|c|c|c|c|c|c|}
\hline Paper & Data & Sample & Dependent variable & Risk measure & Results \\
\hline $\begin{array}{l}\text { Giavazzi and McMa- } \\
\text { hon (forthcoming) }\end{array}$ & SOEP & $\begin{array}{l}\text { 1995-2000 Balanced sample of } \\
\text { households. }\end{array}$ & Savings rates & $\begin{array}{l}\text { Quasi-natural experi- } \\
\text { ment, dummy control- } \\
\text { ling for policy change } \\
\text { that increased future } \\
\text { income uncertainty }\end{array}$ & $\begin{array}{l}\text { The increase in uncertainty of } \\
\text { the future income path leads } \\
\text { to an annual increase in sav- } \\
\text { ings rates of } 3 \% \text {-points. It has } \\
\text { also a large positive effect on } \\
\text { hours worked of part-time work- } \\
\text { ing heads of households. }\end{array}$ \\
\hline
\end{tabular}

Abbreviations: BHPS - British Panel Household Survey (UK); CE - Consumer Expenditure Survey (US); CPS - Current Population Survey (US); FES - Family Expenditure Survey (UK); HRS - Health and Retirement Study (US); INSEE - INSEE Survey on wealth 'Patrimoine 97' (FR); JPSC - Japanese Panel Survey of Consumers (JP); LWR - Laufende Wirtschaftsrechnung "Continuous Household Budget Survey" (DE); NLS - National Longitudinal Survey (CA); PSID - Panel Study of Income Dynamics (US); SAVE - Sparen und Altersvorsorge in Deutschland "Savings and old-age provisions in Germany" (DE); SCF - Survey of Consumer Finances (US); SHIW - Survey of Household Income and Wealth (IT); SIPP - Survey of Income and Program Participation (US); SOEP - Socio-economic Panel Study (DE)

Source: Own compilation 
Table 14: Descriptive statistics for the bivariate random effects probit model by region

\begin{tabular}{lcccc}
\hline & \multicolumn{2}{c}{ West Germany } & \multicolumn{2}{c}{ East Germany } \\
& mean & sd. & mean & sd. \\
\hline$h_{i t}=1$ & 0.131 & 0.338 & 0.134 & 0.341 \\
$e_{i t}=1$ & 0.109 & 0.312 & 0.201 & 0.401 \\
$s_{i t}=1$ & 0.798 & 0.402 & 0.726 & 0.446 \\
$s_{i t}=2$ & 0.093 & 0.290 & 0.073 & 0.259 \\
$s_{i t}=3$ & 0.071 & 0.257 & 0.139 & 0.346 \\
$s_{i t}=4$ & 0.038 & 0.192 & 0.062 & 0.241 \\
Age & 44.334 & 8.624 & 45.232 & 8.521 \\
Foreign nationality & 0.123 & 0.328 & 0.003 & 0.053 \\
Years of education: & & & & \\
7-10.5 & 0.396 & 0.489 & 0.176 & 0.381 \\
edu. 11-12 & 0.297 & 0.457 & 0.528 & 0.499 \\
12.5+ & 0.306 & 0.461 & 0.296 & 0.456 \\
Person in HH needs care & 0.023 & 0.148 & 0.030 & 0.170 \\
Type of household: & & & & \\
Single, no children & 0.113 & 0.317 & 0.118 & 0.322 \\
Single, children & 0.028 & 0.164 & 0.032 & 0.177 \\
Couple, no children & 0.238 & 0.426 & 0.242 & 0.428 \\
Couple, children & 0.555 & 0.497 & 0.573 & 0.495 \\
Other & 0.066 & 0.249 & 0.035 & 0.185 \\
Regional unemployment rate & 9.452 & 3.005 & 18.866 & 2.393 \\
Log other HH income & 0.708 & 0.284 & 0.587 & 0.308 \\
\hline Obs. & 32,719 & & 10,485 & \\
\hline Source: SOEP, own calculation & & & & \\
\hline
\end{tabular}


Table 15: Sample statistics for the wage model by region

\begin{tabular}{lcccc}
\hline & \multicolumn{2}{c}{ West Germany } & \multicolumn{2}{c}{ East Germany } \\
& mean & sd & mean & sd \\
\hline Log hourly wage & 2.787 & 0.423 & 2.384 & 0.459 \\
Bad health & 0.105 & 0.307 & 0.091 & 0.288 \\
Lagged employment status & 0.022 & 0.146 & 0.054 & 0.225 \\
Lagged health status & 0.095 & 0.293 & 0.085 & 0.278 \\
Age & 44.592 & 8.992 & 45.200 & 8.863 \\
Foreign nationality & 0.110 & 0.313 & 0.002 & 0.048 \\
Years of education: & & & & \\
7-10.5 & 0.368 & 0.482 & 0.138 & 0.345 \\
11-12 & 0.303 & 0.460 & 0.525 & 0.499 \\
12.5+ & 0.329 & 0.470 & 0.336 & 0.473 \\
Person in HH needs care & 0.019 & 0.135 & 0.021 & 0.143 \\
Type of household: & & & & \\
Single, no children & 0.112 & 0.315 & 0.106 & 0.307 \\
Single, children & 0.025 & 0.156 & 0.028 & 0.165 \\
Couple, no children & 0.245 & 0.430 & 0.246 & 0.431 \\
Couple, children & 0.553 & 0.497 & 0.584 & 0.493 \\
Other & 0.066 & 0.248 & 0.036 & 0.187 \\
Regional unemployment rate & 9.376 & 2.977 & 18.810 & 2.349 \\
Log other HH income & 0.763 & 0.214 & 0.660 & 0.241 \\
\hline Obs. & 30,110 & & 8,592 & \\
\hline Source: SOEP, own calculation & & & & \\
\hline & & & & \\
\hline
\end{tabular}


Table 16: Wealth regression - coefficients

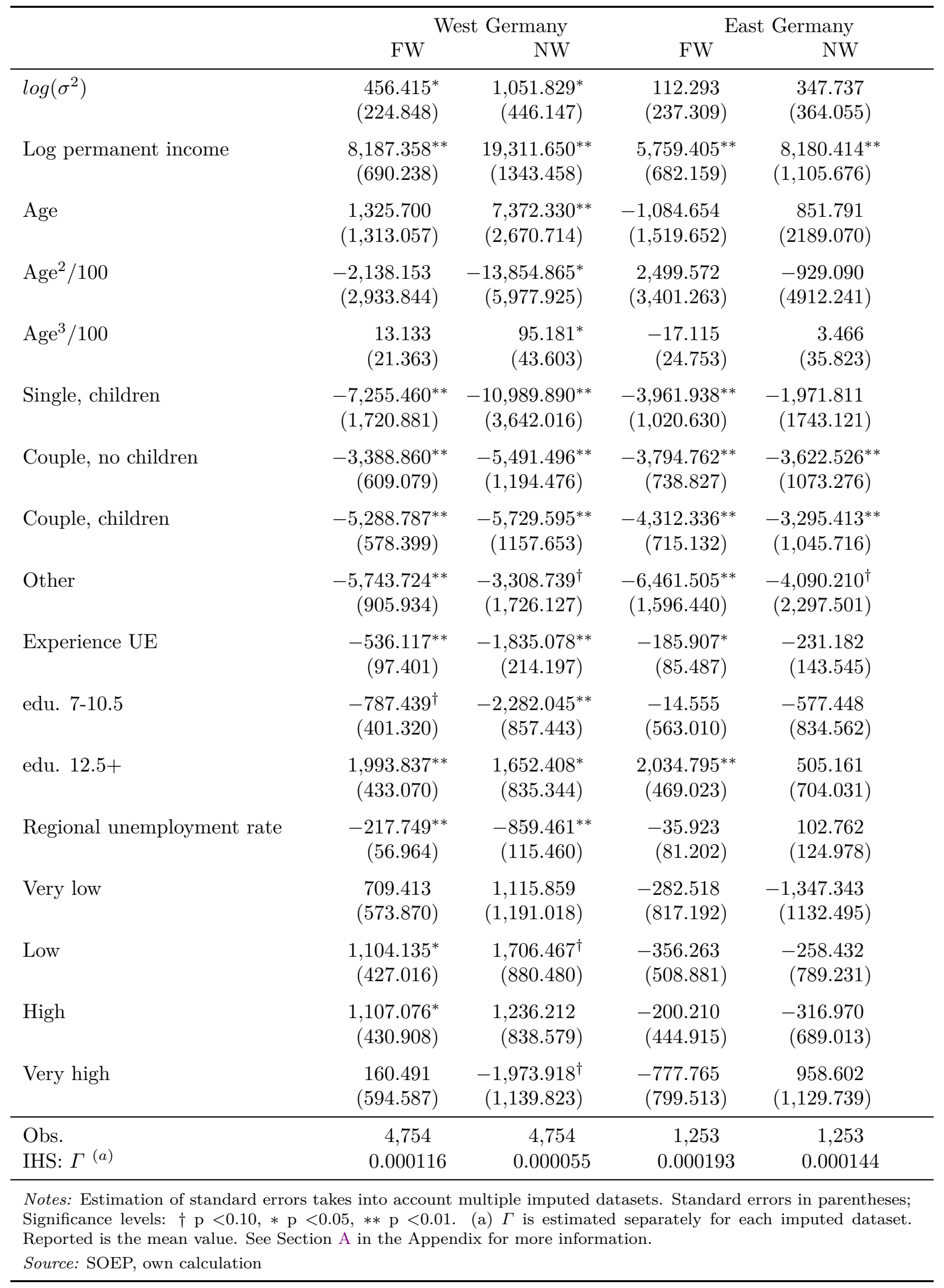




\section{References}

Aiyagari, S. R., 1994. Uninsured idiosyncratic risk and aggregate saving. The Quarterly Journal of Economics, 109(3):659-684.

Alessie, R., Hochguertel, S., and van Soest, A., 2004. Ownership of stocks and mutual funds: A panel data analysis. The Review of Economics and Statistics, 86(3):783-796.

Alessie, R., Lusardi, A., and Aldershof, T., 1997. Income and wealth over the life cycle: Evidence from panel data. Review of Income and Wealth, 43(1):1-32.

Arrondel, L., 2002. Risk management and wealth accumulation behavior in France. Economics Letters, 74(2):187-194.

Bartzsch, N., 2006. Vorsichtssparen und Einkommensunsicherheit privater Haushalte in Deutschland: Eine ökonometrische Untersuchung auf Basis von SOEP-Daten. Vierteljahrshefte zur Wirtschaftsforschung / Quarterly Journal of Economic Research, 75(4):109-120.

- 2008. Precautionary saving and income uncertainty in Germany - New evidence from microdata. Journal of Economics and Statistics / Jahrbücher für Nationalökonomie und Statistik, 228(1):5-24.

Benito, A., 2006. Does job insecurity affect household consumption? Oxford Economic Papers, 58(1):157-181.

Beznoska, M. and Ochmann, R. R., 2010. Household savings decision and income uncertainty. DIW Discussion Papers 1046, DIW Berlin, German Institute for Economic Research.

Browning, M. and Crossley, T. F., 2001. The Life-Cycle model of consumption and saving. The Journal of Economic Perspectives, 15(3):3-22.

Browning, M. and Lusardi, A., 1996. Household saving: Micro theories and micro facts. Journal of Economic Literature, 34(4):1797-1855.

Börsch-Supan, A. and Essig, L., 2003. Household saving in Germany: Results of the first SAVE study. NBER Working Papers 9902, National Bureau of Economic Research (NBER).

Burbidge, J. B., Magee, L., and Robb, A. L., 1988. Alternative transformations to handle extreme values of the dependent variable. Journal of the American Statistical Association, 83(401):123-127.

Caballero, R. J., 1991. Earnings uncertainty and aggregate wealth accumulation. The American Economic Review, 81(4):859-871.

Cagetti, M., 2003. Wealth accumulation over the life cycle and precautionary savings. Journal of Business \&3 Economic Statistics, 21(3):pp. 339-353. 
Carlin, J. B., Li, N., Greenwood, P., and Coffey, C., 2003. Tools for analyzing multiple imputed datasets. Stata Journal, 3(3):226-244.

Carroll, C. D., 1994. How does future income affect current consumption? The Quarterly Journal of Economics, 109(1):111-147.

Carroll, C. D., Dynan, K. E., and Krane, S. D., 2003. Unemployment risk and precautionary wealth: Evidence from households' balance sheets. The Review of Economics and Statistics, 85(3):586-604.

Carroll, C. D., Hall, R. E., and Zeldes, S. P., 1992. The buffer-stock theory of saving: Some macroeconomic evidence. Brookings Papers on Economic Activity, 23(2):61-156.

Carroll, C. D. and Kimball, M. S., 2008. Precautionary saving and precautionary wealth. In Durlauf, S. N. and Blume, L. E., editors, The New Palgrave Dictionary of Economics, pages 579-585. Basingstoke: Palgrave Macmillan, 2. edition.

Carroll, C. D. and Samwick, A. A., 1997. The nature of precautionary wealth. Journal of Monetary Economics, 40(1):41-71.

, 1998. How important is precautionary saving? The Review of Economics and Statistics, 80(3):410-419.

Chamberlain, G., 1984. Panel data. In Grilliches, Z. and Intriligator, M. D., editors, Handbook of Econometrics, pages 1247-1318. Elsevier Science B.V.

Dardanoni, V., 1991. Precautionary savings under income uncertainty: A cross-sectional analysis. Applied Economics, 23(1):153-160.

Deaton, A., 1991. Saving and liquidity constraints. Econometrica, 59(5):1221-1248.

Dreze, J. H. and Modigliani, F., 1972. Consumption decisions under uncertainty. Journal of Economic Theory, 5(3):308-335.

Dynan, K. E., 1993. How prudent are consumers? The Journal of Political Economy, 101(6):1104-1113.

Engen, E. M. and Gruber, J., 2001. Unemployment insurance and precautionary saving. Journal of Monetary Economics, 47(3):545-579.

Essig, L., 2005. Precautionary saving and old-age provisions: Do subjective saving motive measures work? MEA Discussion Paper 84-2005, (MEA), Mannheim Research Institute for the Economics of Aging, University of Mannheim.

Femminis, G., 2001. Risk-Sharing and growth: The role of precautionary savings in the "Education" model. The Scandinavian Journal of Economics, 103(1):63-77.

Fossen, F. M. and Rostam-Afschar, D., 2009. Precautionary and entrepreneurial saving: New evidence from german households. DIW Discussion Papers 920, DIW Berlin, German Institute for Economic Research. 
Frick, J. R., Grabka, M. M., and Marcus, J., 2007. Editing and multiple imputation of Item-Non-Response in the 2002 wealth module of the german Socio-Economic panel (SOEP). SOEPpapers 18, DIW Berlin, German Institute for Economic Research.

Fuchs-Schündeln, N. and Schündeln, M., 2005. Precautionary savings and Self-Selection: Evidence from the german reunification "Experiment". Quarterly Journal of Economics, 120(3):1085-1120.

Geyer, J. and Steiner, V., 2010. Public pensions, changing employment patterns, and the impact of pension reforms across birth cohorts: A microsimulation analysis for Germany. IZA Discussion Papers 4815, Institute for the Study of Labor (IZA).

Giavazzi, F. and McMahon, M., forthcoming. Policy uncertainty and precautionary savings. Review of Economics and Statistics.

Gourinchas, P.-O. and Parker, J. A., 2002. Consumption over the life cycle. Econometrica, $70(1): 47-89$.

Gruber, J. and Yelowitz, A., 1999. Public health insurance and private savings. The Journal of Political Economy, 107(6):1249-1274.

Guiso, L., Jappelli, T., and Terlizzese, D., 1992. Earnings uncertainty and precautionary saving. Journal of Monetary Economics, 30(2):307-337.

Haan, P. and Myck, M., 2009. Dynamics of health and labor market risks. Journal of Health Economics, 28(6):1116-1125.

Hubbard, R. G., Skinner, J., and Zeldes, S. P., 1995. Precautionary saving and social insurance. The Journal of Political Economy, 103(2):360-399.

Hurst, E., Lusardi, A., Kennickell, A., and Torralba, F., 2010. The importance of business owners in assessing the size of precautionary savings. The Review of Economics and Statistics, 92(1):61-69.

Jappelli, T., Pistaferri, L., and Weber, G., 2007. Health care quality, economic inequality, and precautionary saving. Health Economics, 16(4):327-346.

Jäckle, R. and Himmler, O., 2010. Panel data estimates considering selection and endogeneity. Journal of Human Resources, 45(2):364-406.

Kazarosian, M., 1997. Precautionary savings - a panel study. Review of Economics and Statistics, 79(2):241-247.

Kennickell, A. and Lusardi, A., 2004. Disentangling the importance of the precautionary saving mode. NBER Working Papers 10888, National Bureau of Economic Research (NBER).

Kimball, M. S., 1990. Precautionary saving in the small and in the large. Econometrica, 58(1):53-73. 
Kimball, M. S. and Mankiw, N. G., 1989. Precautionary saving and the timing of taxes. The Journal of Political Economy, 97(4):863-879.

Knight, F. H., 1921. Risk, Uncertainty, and Profit. Number 31 in Hart, Schaffner, and Marx Prize Essays on Economics. Boston and New York: Houghton Mifflin.

Kotlikoff, L. J., 1989. Health expenditures and precautionary savings. In Kotlikoff, L. J., editor, What determines savings?, pages 141-162. Cambridge: MIT Press.

Leland, H. E., 1968. Saving and uncertainty: The precautionary demand for saving. The Quarterly Journal of Economics, 82(3):465-473.

Low, H., Meghir, C., and Pistaferri, L., 2010. Wage risk and employment risk over the life cycle. American Economic Review, 100(4):1432-1467.

Lusardi, A., 1997. Precautionary saving and subjective earnings variance. Economics Letters, 57(3):319-326.

- 1998. On the importance of the precautionary saving motive. The American Economic Review, 88(2):449-453.

McDonald, J. F. and Moffitt, R. A., 1980. The uses of tobit analysis. The Review of Economics and Statistics, 62(2):318-21.

Modigliani, F. and Brumberg, R., 1954. Utility analysis and the consumption function: an interpretation of cross-section data. In Kurihara, K. K., editor, Post Keynesian Economics, pages 388-436. New Brunswick: Rutgers University Press.

Mundlak, Y., 1978. On the pooling of time series and cross section data. Econometrica, 46(1):69-85.

Murata, K., 2003. Precautionary savings and income uncertainty: Evidence from Japanese micro data. Monetary and Economic Studies, 21(3):21-52.

Palumbo, M. G., 1999. Uncertain medical expenses and precautionary saving near the end of the life cycle. Review of Economic Studies, 66(2):395-421.

Pence, K. M., 2006. The role of wealth transformations: An application to estimating the effect of tax incentives on saving. The B.E. Journal of Economic Analysis 83 Policy, $5(1): 1-24$.

Ramirez, O. A., Moss, C. B., and Boggess, W. G., 1994. Estimation and use of the inverse hyperbolic sine transformation to model non-normal correlated random variables. Journal of Applied Statistics, 21(4):289.

Rubin, D. B., 1987. Multiple Imputation for Nonresponse in Surveys. New York: John Wiley and Sons. 
Sandmo, A., 1970. The effect of uncertainty on saving decisions. The Review of Economic Studies, 37(3):353-360.

Schunk, D., 2009. What determines household saving behavior? An examination of saving motives and saving decisions. Journal of Economics and Statistics / Jahrbücher für Nationalökonomie und Statistik, 229(4):467-491.

Semykina, A. and Wooldridge, J. M., 2010. Estimating panel data models in the presence of endogeneity and selection. Journal of Econometrics, 157(2):375-380.

Skinner, J., 1988. Risky income, life cycle consumption, and precautionary savings. Journal of Monetary Economics, 22(2):237-255.

Steiner, V., Wrohlich, K., Haan, P., and Geyer, J., 2008. Documentation of the TaxBenefit microsimulation model STSM: Version 2008. Data Documentation 31, DIW Berlin, German Institute for Economic Research.

Wagner, G., Frick, J., and Schupp, J., 2007. The German Socio-Economic Panel Study (SOEP): Scope, evolution and enhancements. Journal of Applied Social Science Studies / Schmollers Jahrbuch, 127(1):139-170.

Wooldridge, J. M., 1995. Selection corrections for panel data models under conditional mean independence assumptions. Journal of Econometrics, 68(1):115-132.

- 2004. Econometric Analysis of Cross Section and Panel Data. Massachusetts: Massachusetts Institute of Technology.

2005. Simple solutions to the initial conditions problem in dynamic, nonlinear panel data models with unobserved heterogeneity. Journal of Applied Econometrics, 20(1):39-54.

Zeldes, S. P., 1989. Optimal consumption with stochastic income: Deviations from certainty equivalence. The Quarterly Journal of Economics, 104(2):275-298. 